\title{
No Room for Singles: A Gap in the Housing Law
}

Single-room occupants (SRO's) are one of the most disadvantaged groups in urban America. ${ }^{1}$ In the low-income hotels of large cities, ${ }^{2}$ each person occupies a solitary room without kitchen or bathroom facilities. Since SRO's do not have written or oral leases for more than a night, they may be evicted at the will of a public official or private landlord. SRO's generally cannot afford standard housing units; the average income of SRO's is about $\$ 1500$ per year, far below the poverty line. ${ }^{3}$ Since SRO's are usually elderly, physically ill, or poorly educated, they lack the ability to increase their livelihood; many depend on transfer payments or transitory labor markets for their insufficient income.

As a disadvantaged group, SRO's need governmental aid to obtain adequate shelter and subsistence. This Note will focus on the housing needs of SRO's. In the past, municipalities have inadequately responded to these needs through a policy of containment. By failing to build proper housing, local officials have helped perpetuate one important aspect of the intolerable, poverty-ridden environment in which most SRO's are forced to live. In recent years, city governments have undertaken a more active policy toward SRO's-clearance. Under the rubric of urban renewal, local officials have torn down residential hotels without providing enough replacements for these structures. Moreover, the federal government has failed to develop construction programs geared to SRO needs, while financially underwriting the demolition of SRO housing.

Local and federal governments have neglected SRO's in part because this sociological group is statistically invisible. Compared to the detailed accounts of general housing conditions, reliable data on SRO's is scarce. ${ }^{4}$ SRO's are also neglected because many are seen as socially

1. In the last comprehensive, national survey of SRO's in $1950,54.7 \%$ of the single men studied lived in substandard housing, as opposed to a general substandard rate for the cities studied of $19.2 \%$. D. BOGUE, SKID Row IN AMERICAN CITIES (1963) [hereinafter cited as BOGUE]. In the same year the rate for urban blacks, some of whom were SRO's, was $60 \%$. U.S. Housing and Home Finance Agency, OUR Nonwhrte Population and its Housıng Table 32 (Government Printing Office, 1963).

2. In 1950, there were forty-one cities with significant numbers of SRO's. Chicago had the largest number of SRO's with over 20,000 , while the average for the forty-one cities was about 5,000. BOGUE, supra note 1 , at 6 .

3. Id. at 10-15.

4. Low-income hotels are frequently overlooked by the Bureau of the Census, which is oriented toward "normal" dwellings like apartments and one-family houses. The Census cannot provide accurate estimates of hotel residency since it groups SRO's indiscriminately 
deviant. ${ }^{5}$ Since most members of nuclear families do not understand the life-style of SRO's, many Americans do not perceive the important social functions played by residential hotels and put these dwellings into the loosely defined category of "slums." Finally, SRO's are ignored because they are powerless. SRO's do not have control over jobs or economic resources that are easily translated into political influence. SRO's are not a large enough group to be courted for their votes; nor are they sufficiently organized to pressure officials into responding to their need for better housing.

Statistically invisible, putatively deviant, and truly powerless, SRO's need new efforts on their behalf. Recently, several serious attacks have been launched at the housing problems of single persons with low incomes. Legal aid lawyers have helped SRO's obtain a temporary injunction to prevent the demolition of low-income hotels in a San Francisco urban renewal project. ${ }^{\circ}$ One housing sponsor in New Haven, Connecticut, is formulating a new building design suitable for low-income single persons. ${ }^{7}$ Public officials are trying to rehabilitate residential hotels in

with other occupants of one-room tenancies like efficiency or studio apartments. Report, The Census-What's Wrong With It, What Can Be Done, 5 Transaction 49, 55-6 (1968).

Although reliable national data on recent SRO trends is virtually non-existent, there have been numerous case studies on SRO's in particular cities. See generally Shid Row, 23 JourNal OF Housing (June 1966).

A large number of case studies have been done in New York City. Bahr, Drinking, Interaction, and Identification: Note on Socialization into Skid Row, 8 JourNAL OF HEALTH AND SOcIAL BeHAvior 272 (1967); Bahr, Worklife Mobility Among Bowery Men, 49 SouthWESTERN SOcIAL SCIENCE QUARTERLY 128 (1968); Bahr and Langfur, Social Attachment and Drinking in Skid Row Life Histories, 14 SocIAL Problems 464 (1967); Bahr and Caplow, Homelessness, Affiliation, and Occupational Mobility, 47 SOcIAL ForcEs 28 (1968); Shapiro, Single-Room Occupancy: Community of the Alone, 11 SOCLAL WORK 24 (1966).

Other studies on SRO's have been done in Chicago, R. Vanderkooi, Relocation of West Madison Skid Row Residents: A Study of the Problem with Recommendations (Prepared May 1, 1967 for the Chicago Department of Urban Renewal) (hereinafter cited as Vanderkooi]; in Sacramento, California, Bauer \& McEntire, Relocation Study: Single Male Population (Redevelopment Agency of the City of Sacramento, 1953); in Philadelphia, $L$. Blumberg et al., The Men on Skid Row (Temple University, School of Medicine, 1960); and in Minneapolis, Minnesota, Caplow, Lovald and Wallace. A General Report on the Problem of Relocation of the Population of the Lower Loop Redevelopment Area (Minneapolis Housing and Redevelopment Authority, 1958).

Demographic estimates for any one city, however, may vary sharply from source to source. For example, in 1950 Bogue estimated 11,400 SRO's in New York City, and said the number of SRO's was declining. BOGUE, supra note 1, at 6, 9. Some years later estimates have run from 50,000, NEW YoRk CITY DEPaRTMENT of Bulldings, STatistical REPORT (1964); to 70,000, N.Y. Times, Nov. 17, 1968, at 1, col. 2-3, 4; to 98,000, Levy, Needed: A New Kind of Single-Room Occupancy Housing, 25 JourNal of Housing 573 (1968).

5. S. Wallace, Skid Row as a WAy of LIFE, chs. 9 and 11 (1965) [hereinafter cited as WALLACE].

6. TOOR v. HUD, Civil Action No. C-69 324 SAW (N.D. Cal. April 29, 1970). Six of the seven plaintiffs representing the class action are residents of low-income hotels.

7. The Student Community Housing Corporation (SCHC) of New Haven, Connecticut, has been working on relocating the SRO's of the city's Strand Hotel, which is slated for demolition in the near future. The SRO's of the Strand would like to stay together, but the renewal authority has already torn down all other low-income hotels in the city. So 
New York and Seattle. ${ }^{8}$ Most importantly, in the post-election session of 1970, Congress passed two laws, the Uniform Relocation Act ${ }^{9}$ and the Moorhead Bill, ${ }^{10}$ which will help SRO's cope with the effect of urban renewal and provide some federal subsidies to construct low-income hotels.

Although these developments are hopeful, they are not adequate responses to the twin governmental policies of containment and clearance. This Note will first describe important characteristics of SRO's and their conflict with central city governments. Second, it will discuss the past federal involvement in the municipal policy of clearance and the impact of the Uniform Relocation Act on SRO's in local renewal areas. Third, it will evaluate the federal subsidies that were available to build low-income hotels and the changes brought about by the Moorhead Bill. Finally, this Note will examine the inadequacies of the Uniform Relocation Act and Moorhead Bill and suggest measures which would provide a more effective response to the shelter needs of SRO's.

\section{SRO's and Local Governments}

\section{A. Some Characteristics of the SRO Population}

SRO's are a unique class within American society. They are predominantly males. ${ }^{11}$ The hotels in which they live are often located near the central business district ${ }^{12}$ because that area contains the main

SCHC, with the cooperation of local officials, has acquired a building near the central business district for SRO use.

In order to plan effectively for the new building, SCHC did intensive surveys on the social, economic, and physical needs of the Strand Hotel residents. SCHC also considered the unique characteristics of the Strand Hotel-the political battles between hotel residents and the renewal authority as well as the historical development of a tightly knit hotel community. [Research on the Strand Hotel project will hereinafter be cited as SCHC Papers.]

8. New York City recently established the Office of Problem Housing in its Housing and Development Administration to deal with the shelter needs of SRO's and other disadvantaged groups. This office has recently begun to rehabilitate several low-income hotels. E. Baer and C. Arner, New Housing for Furnished Room Inhabitants, April 22, 1970 (mimeo report, on file with New York City Housing and Development Administration).

In Seattle, a pilot program has been started at the Frye Hotel. After rehabilitation, the hotel was employed both to house SRO's and to serve as a physical base for social action programs. Abie Label and Associates, The Seattle Plan (Seattle, Washington, 1970).

9. Pub. Law No. 91-1784, 91st Cong., 2d Sess. (1970). For the full text of the bill, see CoNc. REc., 91st Cong., 2d Sess. at H11992-12007 (Dec. 17, 1970).

10. The Moorhead Bill was passed as part of the Housing and Urban Development Act of 1970, Pub. Law No. 91-1656, 91st Cong., 2d Sess. (1970). For the full text of the bill, see CoNG. REc., 91st Cong., 2d Sess, at S20459-20463 (Dec. 17, 1970).

11. SRO's are now mainly a male phenomenon for the simple reason that men cannot have children and form families. However, before World War II, there were some females found in SRO communities. WALLACE, supra note 5 , at 23.

12. Bogue, supra note 1, at 19-45. Locational preferences for housing often reflect the 
sources of SRO revenue-low-skilled factories, service jobs, welfare agencies, and charities. ${ }^{13}$ SRO's are often stereotyped as "drunks," but, in fact, only a relatively small proportion are alcoholics. ${ }^{14}$ According to two major studies on SRO's, many are willing to enter some form of human rehabilitation program. ${ }^{15}$ In the lobbies of residential hotels and on the streets of downtown, SRO's form a community of singles.

While SRO's historically were migrants from rural areas to the city, they are now often products of urban ghettos. ${ }^{16}$ Some are elderly, some are physically disabled, and an increasing number are non-white. ${ }^{17}$ The average SRO ${ }^{18}$ comes from a poor family. Since he usually has little education, he is at the bottom of the employment ladder. Only one out of three SRO's holds a regular job; the others depend on the demand for casual labor. The average SRO has a monthly income around $\$ 150$, of which he pays out $\$ 25-\$ 50$ per month in rent.

There are three distinct explanations why SRO's live in residential hotels. The first theory argues that single, poorly educated men are driven to SRO status by economic circumstances. ${ }^{19}$ It focuses on the failure of the country's school systems and training programs to integrate SRO's into the labor force, rather than on individual failures. A corollary to this theory emphasizes the economics of the housing market. In cities with low-vacancy rates, single men working in low paying jobs find apartment rents unreasonably high. Pensioners or welfare recipients may be given so little money that they are unable to find a decent apartment. ${ }^{20}$

social needs of organized communities. Like SRO's, members of the urban working class, urban villagers, choose to live near the downtown districts. In such a location, working men are often within walking distance of their factories, or at least close by mass transit stops that serve outlying areas. Also, urban villagers in the skilled trades can set up small shops which serve downtown businesses and employees. H. GaNs, Urban Villagers 19-24 (1966).

13. WALLACE, supra note 5 , at chs. 4 and 6 .

14. Serious alcoholics form only $20-30$ per cent of the SRO population. SkID Row, supra note 4, at 3. A large proportion of this alcoholic sub-group drink as a means to escape the reality of their other social problems. BoGue, supra note 1 , at 288 .

15. Bogue states that $74.8 \%$ of SRO's were interested in entering free job training programs. BOGUE, supra note 1 , at 193 . Vanderkooi found that $75 \%$ of those interviewed wanted some type of rehabilitation program. Vanderkooi, supra note 4 , at 25 .

16. Bogue, supra note 1 , at 243-4.

17. Id. at 106-7; Vanderkooi, supra note 4, at 16 .

18. The statistics on the average SRO are taken from Bogue, supra note 1 , at 10-15, and Vanderkooi, supra note 4 , at 13-18.

19. Bogue favors this explanation. He states, "Individual men gravitate to Skid Row far more frequently because of irregular employment, unemployment, and low income, than because of alcoholism." Bogue, supra note 1, at 404.

20. In San Francisco, for example, workingmen have been forced to live in residential hotels because the vacancy rate in 1969 for one-room studio apartments renting at under $\$ 100$ per month was between zero and $.3 \%$ and the rate for one-bedroom units in the same price category was zero. San Francisco Department of City Planning, Survey of Housing Table 3 (Housing Report 3, Dec., 1969). 
A second explanation states that persons are forced into SRO status because social institutions do not adequately respond to the needs of the disadvantaged. ${ }^{21}$ An SRO may not be so mentally or physically ill as to qualify for admission to state medical institutions, but still be so infirm that he cannot find shelter other than in a low-income hotel.

In sharp contrast to the first two explanations, the third suggests that men live in residential hotels because they like this style of living. ${ }^{22}$ In any society there are groups who refuse to accept the prevalent social norms; they form a subculture of their own, ${ }^{23}$ which has a welldefined set of social mores. Like the working class families studied by Gans, ${ }^{24}$ SRO's remain in their subculture because the benefits of personal tolerance outweigh the costs of isolation from the larger community.

Thus, SRO's live in residential hotels rather than apartments because they offer cheaper rentals, because SRO's are too infirm to find any better place to live, or because SRO's prefer the hotel style of life..$^{25}$ All low-income hotels provide small rooms with common bathroom facilities; they also usually supply large lobbies and services like room-clean-

In many cities, welfare departments encourage recipients to live in residential hotels as a way of conserving funds. Bocue, supra note 1 , at 54-5. Moreover, in some places, the structure of welfare payments acts as an incentive to become a SRO. For example, the New York City Department of Welfare pays an average of $\$ 82.45$ for a furnished room but only $\$ 65.75$ for an unfurnished unit. N.Y. Times, Nov. 17,1968 , at 1 , col. 1-2.

21. Shapiro takes this view. Shapiro, supra note 4. She says, "Unattached single individuals constitute a group of the poor population characterized by marked social and psychological maladaptation and chronic physical disease; they are neither sick or deviant enough to be institutionalized nor well enough to use health, social and welfare services effectively." Id. at 24.

22. WALLACE, supra note 5 , at 128 .

23. SRO's are disaffiliated from the larger society. They have fewer ties with social organizations than lower-class men from family neighborhoods. Bahr and Caplow, supra note 4. The more SRO's interact with other single men, the less they have social relations with persons outside of SRO areas. Bahr, Drinking, Interaction, and Identification: Note on Socialization into Skid Row, 8 JourNaL OF HEALTH AND SOcIAL BfHavior 272, 284 (1967).

Older men often choose to live in residential hotels for a society of their peers. Bogue, supra note 4 , at 50 . Workingmen in residential hotels sometimes form informal corporations that serve as insurance agencies to its members. Id. at 57 . The same form of insurance has been found among panhandlers. WALLACE, supra note 5, at 157-8. The bottle gangs, which pool their resources to obtain drink at the lowest per unit prices, have been noted for their cooperative features. Id. "Hippies" in the SRO category have their own communal style of living. Vanderkooi, Changing Ecological Patterns of Homeless Men, Spring 1970 (paper presented to Illinois Sociological Society).

24. H. GANs, supra note 12 , at chs. 2 and 11 .

25. Subcultures often have unique housing preferences in line with their social priorities. The urban villagers, for example, preferred to live cheaply in old two-family houses although many could afford better homes of their own. This housing arrangement served two functions simultaneously: more money for durable consumer goods, and an opportunity to share a house with members of their extended families. H. GaNs, supra note 12, at 12-16, 182-7. For a discussion of the social functions served by particular types of dwellings, see Rainwater, Fear and the House-as-Haven in the Lower Class, $32 \mathrm{~J}$. AM. INST. PLANNERs 23-31 (1966). 
ing. As single persons, SRO's require places to congregate and socialize; they often need someone to make their beds and wash their clothes.

While sharing certain general characteristics, low-income residential hotels are of two distinct types. One type ${ }^{26}$ contains elderly pensioners, those who desire hotel residency, and single working men who cannot find cheap, decent housing in the local apartment market. The rooms are generally sanitary and the common places are well-maintained. This type usually develops a long-term clientele who form a coherent community. The other type of hotel ${ }^{27}$ attracts the unemployed, the alcoholic, the physically handicapped, and the mentally ill. The rooms may be small cubicles roofed with chicken wire to protect against thieves; the hallways may be in a dilapidated condition. This type has a relatively transient clientele who generally have little interaction.

\section{B. The Municipal Response}

The needs of SRO's, as physically expressed in both types of residential hotels, directly conflict with the economic interests of city governments. Municipalities derive most of their revenues from property taxes, which have traditionally been supported by industrial holdings and middle-class homes. After World War II, firms left the central city because of increasing traffic congestion, land costs, and property taxes. ${ }^{28}$ Homeowners followed firms for a variety of reasons-racial prejudice, deteriorating schools, or the social status of a suburban address. ${ }^{29}$ At the same time, the influx of rural poor, together with the population boom in the urban ghettos, greatly increased local expenditures on social services. ${ }^{30}$

26. The Strand Hotel in New Haven, studied by SGHC, is a good example.

27. For detailed description and photographs of this second type, see Bocue, supra note 1 , at $79-90$.

28. For the last two decades, employment in suburban manufacturing, wholesaling, retailing, and service industries has been increasing at an annual rate of over $10 \%$, whilc central city employment in these four categories has declined or stayed the same. John Kain, The Distribution and Movement of Jobs and Industry, in METROPOLITAN ENIGMA (J. Wilson ed. 1967).

For discussion of the movement of jobs and industry within metropolitan areas, see e.g., R. Vernon, The Changing Economic Functions of the Central City (1959); D. CREAmer, Changing Location of Manufacturing Employment (1963).

29. Out of the twenty-two largest central cities in America, only nine showed any rise in the white population from 1950 to 1960; every one of these cities increased its number of Negro inhabitants, some by over $100 \%$. INTERgovernMENTAL ReLATIONS SubcomMitTEE of the Senate Committee on Governifental Operations, Metropolitan anierica: ChalLENGE TO FEDERALISM 18 (1966).

For a discussion of the extent, causes, and implications of suburban growth, see C. Tunnard, America's Super-Cities, 217 HARPER's MACAzINE 59 (1958); H. Eldredge, People: Urbanization and City Growth in 1 Taming Megalopolis 93 (H. EldRedge ed. 1967); J. GotTMAN, MEgalopolis (1961); E. and G. Grier, Equality and Beyond: Housing Segregation in the Great Society, 95 DAEDALUS 77 (1966).

30. In the period from 1957 to 1965 , per capita expenditures of central cities on pub- 
As industry moved out, even able-bodied SRO's were transformed from an important source of unskilled labor to a public welfare burden. ${ }^{31}$ Many of the firms remaining in the central city introduced automated processes which require high-skill workers. As homeowners left, city officials became more conscious of the low property taxes paid by residential hotels relative to their central locations. ${ }^{32}$

Caught between increasing costs and decreasing revenues, municipalities chose to ignore the serious problems of SRO's, instead of rehabilitating substandard buildings, retraining able-bodied men, and caring for the physically or mentally ill. ${ }^{33}$ No efforts were made to stop the economic exploitation of SRO's regularly practiced by employment agencies, employers, and restaurants. ${ }^{34}$ Local government supplied hotels with the minimum protection by police, who often took advantage of owners and residents. ${ }^{35}$

With the advent of urban renewal, local governments grasped the opportunity to tear down low-paying hotels and replace them with civic

lic services rose by $45.9 \%$. D. Netzer, Financing Urban Government, in The MrmopowTAN ENigma 58 (J. TVilson ed. 1967).

For a discussion of the implications of urban economic and demographic trends for city finances, see C. Tilly, Race and Migration to the American City in TuE Metnopoutan Enigma 124 (J. Wilson ed., 1967); D. Moynihan, Poverty in Cities in THE MEthopol. TAN ENIGMA 300 (J. TVIrSON ed., 1967); and R. Vernon, The Economics and Finances of The Large Metropolis, 90 DaEdalus 31 (1961).

31. Slightly less than one-half of all SRO's receive some form of public assistance. Bocue, supra note 1 , at 103 , and Vanderkooi, supra note 4 , at 13 .

32. A study of SRO areas in New York City over the last century found that land values had stayed the same in these places, while the price of property in the rest of Manhattan had multiplied by five times. Sigal, The Unchanging Area in Transition, 43 LAND ECONOMYCS 284, 287 (1967).

33. Bogue says, "Rather than create a coherent program of help and reliabilitation, society temporizes by quarantining the men in a particular section . ..." Bocue, supra note $\mathrm{I}$, at 406 .

While welfare and charitable organizations sometimes offer food, clothing, and health care, SRO's resent these institutions because of their paternalistic attitudes. Wallace describes the SRO's relation to such agencies as an exercise in role playing, with the SRO meeting the minimum behavioral standard to obtain what is being handed out. W'Allace, supra note 5, at ch. 4 .

Containment as a municipal policy is legally suspect. Cities should implement their own ordinances-on sanitary food, police protection and usury-for the bencfit of SRO's as well as other local citizens. Cities should enforce local housing codes in low-income hotels together with fair rent ordinances or other measures to prevent landlord retaliation against SRO's. For a discussion of differential enforcement of city ordinances, see Ratner, Inter-Neighborhood Denials of Equal Protection in the Provision of Mfunicipal Setvices, 4 HaRv. Civ. Righrs-Civ. LIB. L. REv. 1 (1968).

34. Employment agencies usually take one-third or more of SRO wages. Emplosers often do not pay them the minimum wage or give them Social Security credits for jobs clearly eligible. Restaurants and taverns loan money to SRO's at usurious rates-interest of $50 \%$ over a three-day period is common. Eating and drinking places sometimes serve SRO'S food that violates public health standards. Bogue, supra note 1 , at at 459.94 .

35. Some policemen receive "protection money" from both SRO's and hotcl ouners. Officers have been known to beat SRO's brutally or arrest them spuriously for loosely defined crimes like vagrancy. Bogue, supra note 1 , at $492-3$ and WALLAcE, supra note 5 , at ch. 7 . 
centers and shopping malls attractive to wealthy homeowners. ${ }^{30}$ Lack of replacement housing acted to drive SRO's out of town. Other measures were also taken to exclude SRO's. Cities passed ordinances requiring the deconversion of SRO units formed previously by subdividing apartments. ${ }^{37}$ Municipalities used zoning codes to outlaw units inhabited by more than four persons unrelated by blood. ${ }^{88}$

\section{The Federal Role in Clearance}

The federal government has played a central role in enabling municipalities to carry out programs of SRO clearance. Through subsidization of urban renewal, it helps finance the planning of SRO removal, the demolition of residential hotels, and the development of parcels previously occupied by SRO buildings. ${ }^{30}$

In addition to simply supplying financing, federal renewal law has weighted the relocation process against SRO's after they were forced out of their residences; and, under current doctrines, effective remedies for SRO's are not available in the courts. While the Uniform Relocation Act has increased the monetary benefits for displaced SRO's, it avoids the most crucial problem-adequate relocation housing.

\section{A. SRO's and the Relocation Process}

The relocation process has been weighted against SRO's at two stages. Prior to the Uniform Relocation Act, SRO's were denied many monetary benefits after displacement. Even now, SRO's are less able to find suitable relocation housing either in the existing rental market or in new units.

36. As examples, in New Haven, Conn., a city known for its "progressive" rencwal program, the city tore down all but one of the original dozen or so residential hotels; thic last is slated for demolition. No new facilities have been built. SCHC Papers, stupra note 7. In Stockton, California, a nine-block area of SRO housing was replaced by a cominer. cial district and convention hall. Skid Row, supra note 4, at 6. In Oklahoma City, Okla* homa, one site in a renewal area, which had housed 267 SRO's, was cleared for the construction of a theater. Levy, supra note 4 , at 575 .

SRO's are only one of many powerless groups who have been sacrificed in the interest of property owners. For a discussion of distribution of urban renewal's costs and benc. fits, see, e.g., W. VON EGKARDT, BULLDOZERS AND BUREAUGRATS: CITIES AND URUAN RENEWAL (1963); URBan Renewal: The Record and the ControversY (J. Wilson ed. 1966).

37. In New York City, the deconversion would ultimately force $\mathbf{3 0 , 0 0 0}$ to 70,000 SRO's to find new places to live. Apartments with one bathroom for more than six tenants aro already unlawful, while deconversion of all subdivided apartments is requircd by July 11, 1977. N.Y. Times, Nov. 17, 1968, at 1, col. 2.

38. A good example is Amendment to $\S 1$. Definitions of the Code of Ordinances of the City of New Haven (Family), NEw HAven ZoNing CoDe 533 (Operative July 28, 1969).

39. The federal government contributes two-thirds of the cost of local renewal projects, 42 U.S.C.A. \& $1453(\mathrm{a})(2)$. 
Before this year, unless SRO's were disabled or elderly, they could not receive the Additional Relocation Payment (ARP) of up to $\$ 500$ per year for two years after displacement.0 If SRO's do not have the same mailing address for ninety consecutive days before displacement, they still are ineligible for any relocation benefits. ${ }^{11}$ This provision is a serious burden on many SRO's who either have no mailing address or who switch hotels periodically. Even if SRO's meet the ninety day requirement, those without furniture are given only a flat sum of five dollars for moving expenses. ${ }^{42}$

Although displaced SRO's are by law required to be given a decent, sanitary unit, ${ }^{43}$ in practice there is often no appropriate standard housing in the existing market. In finding SRO's a place to live, HUD does not have to consider unique living styles or communal organizations. ${ }^{44}$ While SRO's may want to continue living in hotels, existing SRO buildings are usually overcrowded or themselves slated for demolition. SRO's cannot afford the rent of most standard apartments; and apartment owners do not like to accept SRO's because of their alleged social deviancy. ${ }^{45}$

In order for a new low-income hotel to be built on cleared land, HUD demands a costly and time-consuming survey on the market for transient housing. ${ }^{40}$ More importantly, the 1969 Weicker Amendment, designed to require municipal construction of sufficient relocation housing, does not apply to SRO's. ${ }^{47}$ This amendment requires that each family unit demolished in urban renewal be replaced by a new one within the jurisdictional area of the renewal authority. Replacement of the SRO units demolished is not required.

40. 42 U.S.C.A. $\S 1465$ (c)(2).

41. For a discussion of the 90-day limitation, see Shid Row, 23 Journal of Fousing 3-4 (June 1966).

42. 24 C.F.R. $3.105(b)(2) i(1970)$.

43. 42 U.S.C.A. \& 1455 (c)(1).

44. Id. The section say's only that the relocation area, as compared to the original neighborhood, must not be "generally less desirable in regard to public utilities and public and commercial facilities...."

45. For example, in a Minneapolis renewal project, $44 \%$ of SRO's before reloeation paid less than $\$ 20$ per month for rent, while after relocation only $2.4 \%$ spent less than $\$ 20$ a month on housing. Vanderkooi, supra note 4 , at 6 . For a discussion of the discriminatory rental market faced by displaced single persons in Pittsburgh, see Hearings on Housing and Urban Development Legislation-1970 Before the Subcomm. on Housing of the House Comm. on Banking and Currerncy, 9lst Cong., 2d Sess., at 322 (1970) (statement of J. David Barkley).

46. 42 U.S.C.A. \& $1456(\mathrm{~g})$. This section was inserted at the request of the American Hotel Association. The request can be found in Hearings on $S .57,65,193,198,195,266$, $271,272,336,543,612,655$ Before the Senate Comm. on Banking and Currency, 86th Cong., Ist Sess., at 754-5 (1959); and Hearings on H.R. 2357, 3319, 1300, and H.J. Res. S9 Before the Subcomm. on Housing of the House Comm. on Banking and Currency, 86th Cong., lst Sess., at 705-06 (1959).

47. 42 U.S.C.A. \$ $1455(\mathrm{~h})$. 


\section{B. Judicial Barriers to Standard Housing for SRO's}

While SRO's have been clearly harmed, both in terms of benefits and relocation housing, by the federal displacement process, judicial review has been concerned primarily with relocation housing.48 ${ }^{48}$ For years, SRO's and owners of residential hotels could not obtain effective judicial redress for their injuries because of a restrictive interpretation of standing requirements. ${ }^{49}$ Since the criteria for standing have been liberalized, ${ }^{50}$ both groups are now afforded the opportunity to have their grievances heard on the merits. But since there is no constitutional right to a decent place to live, ${ }^{61}$ SRO's are unable to construct legal arguments on which they could actually win their cases. While SRO's could plead specific violations of the renewal law, local agency violation of the right to live in a city, or federal legislative exclusions not reasonably related to statutory purpose, each line of

48. Before the Uniform Relocation Act, SRO's had no substantial monctary bencfits to protect. Now they should be able to obtain the money payments available under the Act. See p. 412 infra.

49. Hotel owners were denied standing to challenge the construction of a competitor in a renewal project. Taft Hotel Corp. v. HHFA, 262 F.2d 307 (2d Cir. 1958), alt'g $16 \%$ F. Supp. 538 (D. Conn. 1958). Community groups were denied standing to challenge rc* location plans in Green Street Association v. Daley, 373 F.2d 1 (7th Cir. 1967), cert. den'd, 387 U.S. 932 (1967); and Johnson v. Redevelopment Agency of the City of Oakland, 317 F.2d 872 (9th Cir. 1963), cert. den'd, 375 U.S. 915 (1963). See Note, Judicial Review of Displacee Relocation in Urban Renewal, 77 YALE L.J. 966 (1968).

50. Association of Data Processing Service Organization, Inc. v. Camp, 397 U.S. 150 (1970); Barlow v. Collins, 397 U.S. 159 (1970). The Supreme Court said that standing would be granted if a person had in fact been injured or threatened with irreparable harm, ard was in the zone of interest of the relevant statute or constitutional mandate. The injury test derives from the Article III requirement of adverseness; the zone of interest criterion comes from the "aggrieved person" standard of the Administrative Procedure Act, 5 U.S.C.A. \$ 702. The Supreme Court made clear that the concept of injury should not be limited to economic harm. Injury may reflect aesthetic, conservational, recreational or spiritual values, as well as economic harm. 397 U.S. at 154. The Supreme Court also said the zone of interest should be construed broadly. 397 U.S. at 154.

Lower courts had earlier allowed standing to displaced persons on other grounds. Sce Norwalk Core v. Norwalk Redevelopment Authority, 395 F.2d 920 (2d Cir. 1968); Western Addition Community Organization v. Weaver, 294 F. Supp. 433 (N.D. Cal. 1968); 1'ow(1. ton Civic Homeowners Association v. HUD, 284 F. Supp. 809 (E.D. Pa. 1968), Sec also Tondro, Urban Renewal Relocation: Problems in Enforcement of Conditions on Falleral Grants to Local Agencies, 117 U. PA. L. REv. 183 (1968).

Thus, both SRO's and hotel owners should have their cases heard on the merits. When low-income hotels are torn down, SRO's may be injured by the psychological loss of sc. curity, the physical hardship of finding a new place, and the financial burden of higher rents; and the federal relocation statute was designed to help those, like displatcel SRO's, forced out by renewal projects. 42 U.S.C.A. \$ 1455. Owners of low-income hotels may be economically harmed because they are put out of business; and the housing survey tequired by the renewal act, 42 U.S.C.A. \& $1456(\mathrm{~g})$, was aimed at insuring a local market for transient housing which would not be harmful to existing hotels. Moreover, in Asso. ciation of Data Processing Service Organization, Inc. v. Camp, 397 U.S. 150 (1970), the Court specifically approved standing for plaintiffs claiming financial harm through in. creased economic competition.

51. See Michelman, Advent of a Right to Housing: A Current Appraisal, 5 Hanv. Civ. RiGHTS-CIv. LIB. L. REv. 207 (1969). 
attack on SRO problems is fraught with difficult practical or theoretical problems.

\section{(1) Agency Violation of Relocation Provisions}

As in current litigation challenging proposed demolition of low income hotels in San Francisco, SRO's have usually argued that HUD should not approve the local renewal agency's plans because they were formulated without the procedural safeguards and assurances of adequate relocation housing required by statute..$^{52}$

Arguments based on alleged violations of renewal statutes are very difficult to prove. If SRO's plead legislative violations, then they have to demonstrate statistically that there are not enough vacancies in the existing housing market to cope with the displacement of large numbers of single men. In most cases, uneducated SRO's do not have lawyers with the expertise needed to overcome the statistical barrage of local market surveys generated by the agency's full-time, professional staff. ${ }^{*}$ Even when SRO's can obtain technical aid, the factual issues are so complicated that the trial is extremely long. For example, in the San Francisco case the SRO's were in court almost a year until the controversy was temporarily settled.54 Finally, to win a case alleging legisla-

52. Complaint of TOOR (Declaratory and Injunctive Relicf, TOOR v. HUD, Civil Action No. C-69 324 SAW (N.D. Cal. 1970).

53. In the San Francisco case, the SRO's were fortunate to obtain the assistance of city planning experts from a nearby university. See Community Design Center at the University of California Extension, Housing Proposal for the Yerba Buena Redevelopment Project June, 1970 (prepared for Toor).

54. TOOR v. HUD, Civil Action No. C.69 324 SAW (N.D. Cal. 1970). In the spring of this year, Judge Weigel handed down a preliminary injunction in favor of the plaintift SRO's because he found that the federal government should not have approved the renewal plan for the Yerba Buena Center. Judge Weigel said that the San Francisco Redevelopment Agency had not provided adequate assurances of relocation housing, and had not consulted minority groups, as required by federal statutes. TOOR v. HUD, Civil Action No. C-69 324 SAW, Findings and Conclusions for Preliminary Injunction: Orders on Motions for Dismissal and Partial Summary Judgment dated April 29, 1970. The preliminary injunction restrains the Agency from in any way attempting to move SRO's out of the renewal area or demolish any residential structures within the area. The court order enjoins HUD from honoring requisitions from the local agency for financing of the Yerba Buena Redevelopment project. TOOR v. HUD, Civil Action No. C-69 324 SAW. Preliminary Injunction, April 29, 1970.

On May 25, 1970, Edmund G. Brown, former governor of California, was appointed as master to aid the court in arriving at a just resolution of the conflict around the Yerba Buena project. After four lengthy conferences with counsel and other spokesmen for the parties, Brown found that a minimum of 2,000 units of new low-rent housing beyond current plans would be desirable to house the 1,500 people in the Yerba Buena area and others being displaced currently by renewal projects in the Western Addition section of San Francisco. He therefore recommended that the agency submit to the court by September 15, 1970, a list of sites of its own choosing within the city on which 2,000 units of low-income housing could be built. Findings, Recommendations, and Order of Special Master, June 18, 1970. The Master's report was accepted by Judge Weigel. Order Re: Special Master's Report, Aug. 3, 1970. But the development agency rejected the Mraster's report because they felt that the existing housing supply could absorb all displacees from 
tive violations, SRO's have the burden of persuading a court that the agency abused its discretion. Courts have been deferential to the expert judgments made by city planning departments; and HUD's prior approval of a local agency's plans currently carries great weight with the judiciary. ${ }^{55}$

\section{(2) Equal Protection: The Right to Live in a City}

Relying on similar holdings in Norwalk Core v. Norwalk Redevelop. ment ${ }^{56}$ and Arrington $v$. City of Fairfield, ${ }^{\text {tr }}$ SRO's could also argue that renewal which forced a particular class out of a city violated the Equal Protection Clause. ${ }^{58}$ Their success would depend on the standard of review applied by the Court.

the Yerba Buena area. Instead, a new relocation plan for Yerba Buena was submitted by the local redevelopment agency to HUD. The major difference in the now plan is thic granting of special preference to displacees from this project for entry into public housing, Letter from Amanda Fisher, co-counsel for TOOR, to Robert Pozen, Scpt. 14, 1970.

Recently Judge Weigel was able to reach a compromise settlement with counscl from both sides. This compromise, however, was soundly rejected by the plaintiff SRO's، So Judge Weigel has dissolved the injunction against the rencwal authority and issucd a court order which directs the authority to construct 1,500 units of low-income housing within the next three years. The renewal authority is not allowed to tear down five exist. ing residential hotels with a total of about 500 rooms until it carries out the court's or. der. Memorandum Concerning the Court's Order of November 9, 1970; and telcphonc interview with Amanda Fisher, co-counsel for plaintiffs, Nov. 12, 1970.

55. While the Uniform Relocation Act will place such a case under the Administrative Procedure Act, there will be no change in the standard of proof. See note 99 infra.

56. 395 F.2d 920 (2d Cir. 1968). In Norwalk, Connecticut, the local urban renewal agency drew up plans to demolish low-income units, including SRO buildings, without providing for adequate replacements. There were no vacancies for low-income persons in the rest of the city, and the private housing market discriminated against minority groups. Once dis* placed, these groups would have in effect been forced to leave the city.

The Norwalk court held that renewal officials would be acting illegally if they intended that the project, together with the well-known discrimination in the local housing anar. ket, act to exclude minority groups from the city. The court went further and sald that the plan would be invalid even if the exclusion of minority groups was unintended, rclying on Judge J. Skelley Wright's opinion in Hobson v. Hansen, 269 F. Supp. 401, 497 (D.D.C.), affirmed sub. nom. Smuck v. Hansen, 408 F.2d 175 (D.C. Cir. 1969).

57. 414 F.2d 687 (5th Cir. 1969) (Motion to dismiss and motion for summary judgment). In Arrington, the federal government refused to underwrite a proposed urban renewal project because the plans did not meet HUD relocation standards. A private realty company then decided to clear land and build a motel in what was to be the rencwal arca. To assist this project, the city administration agreed only to install storm sewers and cover a tar ditch. Community groups as plaintiffs alleged that motel construction would cllsplace many low-income families, predominantly blacks, who would not be able to find new places to live in Fairfield because of rampant discrimination in the private housing market. Since there was no involvement with the federal renewal program, the court had to base its opinion solely on the equal protection clause. In holding for the community group, the court said that a city cannot participate in a project which it knows will force a class of persons outside of municipal limits, even though the discrimination is accoll. plished by private means.

58. Residential hotels are located in one or two distinct areas in most cities, generally marginal neighborhoods close to downtown and invariably first priorities for urban renewal. See pp. $397-98$ supra. When these areas are levelled by renewal projects, there are no other residential hotels. SRO's are too poor to afford the rents of traditional urban apartments; and they are subject to discrimination in the private rental markct of the city which is oriented toward housing families. In effect, renewal may drive SRO's out of town. 
Under standard Equal Protection doctrine, government classifications are invalid only if they are not rationally related to a valid public purpose. ${ }^{59}$ SRO's would first have to show statistically that they were excluded from relocation opportunities in the housing market of the particular city. Then they would have to surmount the judicial presumption that the policy which resulted in SRO exclusion is rationally related to some valid public purpose. Since the needs of SRO's often conflict with the economic interests of municipalities, it would be almost impossible for SRO's to demonstrate that their exclusion was not rationally related to a permissible goal. ${ }^{00}$

To win an Equal Protection argument, SRO's would have to convince the court to apply the compelling state interest standard, a more rigorous alternative to the traditional rational relation standard, in reviewing the validity of the municipality's action. Under this standard, the city would have to demonstrate a compelling interest in the clearance of SRO housing. ${ }^{.1}$ Outside the area of military security, the state has historically almost never been able to meet this burden. ${ }^{62}$

The compelling state interest standard is imposed under two types of conditions. First, the standard is used if a classification is "suspect"-if it involves differential treatment of certain disadvantaged minorities.03 Second, the standard is applied when a classificatory scheme restrains the exercise of a citizen's fundamental rights. ${ }^{\text {os }}$ The exclusion of SRO's from a city through renewal may arguably trigger review in either way.

As a very disadvantaged minority, ${ }^{05}$ SRO's might qualify as a suspect category, as did the plaintiffs in Norwalk and Arrington. The difficulty

59. Lindsley v. Natural Carbonic Gas Co., 220 U.S. 61,78 (1911). Sce generally Note, Developments in the Law: Equal Protection, 82 HARv. L. REv. 1065, 1076-57 (1909) [hereinafter cited as Developments].

60. Cf. Dandridge v. Williams, 397 U.S. 471, 486 (1970): "We need not cxplore all the reasons that the State advances in justification of the reguiation. It is enough that a solid foundation for the regulation can be found in the Statc's legitimate interest in encouraging employment and in avoiding discrimination between velfare families and the families of the working poor."

61. Developments, supra note 59, at 1087-1132.

62. See, e.g., Korematsu v. United States, 323 U.S. 214 (1944).

63. The clearest example of a suspect category is blacks, Developments, supra note 59 , at 1087-1104, although the courts have extended the suspect label to certain subgroups of the poor. See Harper v. Virginia Bd. of Elections, 383 U.S. 663 (1960); Douglas v. California, 372 U.S. 353 (1963); and Note, Discrimination Against the Poor and the Fourtecnth Amendment, 81 HARv. L. REv. 495 (1967).

64. For example, in recent cases on welfare residency requirements, the Court made clear that the State had to show a compelling interest in such requirements because they restrained the fundamental right to travel. Shapiro v. Thompson, 394 U.S. 618 (1969).

65. SRO's are in many ways as deprived a minority as blads. In terms of quality of housing, SRO's live in as substandard conditions as blacks. See note 1 supra. In relation to income, SRO's earn less money than non-whites on the average. In regard to childhood backgrounds, SRO's come from as disadvantaged families as most blades. BocuE, supra note 1 , at $14-15$. 
with this approach, however, is that in both Norwalk and Arrington the class excluded was blacks, and in moving from race as a suspect category to some sub-group of the poor like SRO's, serious problems arise."0 While the Court may be seen as protecting certain sub-groups of the poor through suspect category analysis in cases involving state voting and criminal appeals by indigents, ${ }^{67}$ the Court has not begun to suggest guidelines making clear which sub-groups of the poor are to be accorded special judicial treatment in other settings. The cases have not demarcated the attributes of the particular sub-groups themselves which could be applied as limiting criteria. ${ }^{68}$ Rather, the main difference between the sub-groups of the poor afforded special judicial treatment is the importance of the right denied-criminal appeals and voting-a differentiation which seems to move away from suspect classification status toward the concept of fundamental rights.

SRO's could also attempt to trigger the compelling state interest standard of review by convincing the Court that their fundamental rights to travel were at stake. In the welfare residency cases, the Court made clear that the right to travel included the right to reside or migrate to the state of one's choice. ${ }^{69}$ SRO's could argue that if residential hotels were torn down without the provision of replacements, SRO's living in the city would in effect be driven out, and SRO's in other areas would be strongly deterred from moving to the city.

The problem with this argument is that any unfavorable difference between municipalities, in residency requirements for services or in actual level of services, is in a sense a deterrence to inhabitation or migration. ${ }^{70}$ Since the Court is not going to make all state laws identical,

66. It would seem that even the nature of the analysis shifts when poverty is to be considered suspect. When one considers more traditional categories, like race, alienage", or illegitimacy, the concern is with the kind of category. When onc considers a subgroup of the poor, the focus must shift to one of degree. The question becomes whether thiss sub-group of the poor is more or less deprived than other subgroups-a very difficult question if lines are to be drawn rationally by a court.

67. For a full explication of this interpretation of recent equal protection cases, sce Michelman, Foreword: On Protecting the Poor through the Fourteenth Amenclment, 83 HARV. L. REV. 7 (1969).

68. Yet proximity to the subsistence level of existence seems to be onc characteristlc of sub-groups of the poor selected for special judicial treatment. Goldberg v, Kelly, 397 U.S. 254, 260-66 (1970). Many SRO's are living very close to the subsistence level. Anotlier criterion for distinguishing sub-groups of the poor might be judicial managcability. SRO's are a very manageable group for the courts since they all share the same design needs and most have incomes in the lowest strata of the poverty bracket.

69. Shapiro v. Thompson, 394 U.S. 618 (1969). The argument that the right to travel is a fundamental interest has already been applied to the housing ficld. The First Circult has held that residency requirements for public housing violate the right of travel of low-income persons who could not otherwise reside within the unit's boundaries. Cole v. Newport Housing Authority, 39 U.S.L.W. 2320 (1st Cir. 1970).

70. Thus, if residency requirements for public housing infringe upon the fundantental 
SRO's would be forced to show why the demolition of residential hotels is particularly burdensome on the right to travel. SRO's could find support in the zoning cases holding that exclusion of low-income groups by large lot requirements is illegal. ${ }^{71}$ But no court has said that exclusions caused by urban renewal are illegal except if the excluded group is a suspect category. ${ }^{2}$

If SRO's could not fit themselves neatly into either the suspect category or fundamental interest branches of the compelling interest standard, they could interpret recent decisions as applying a sub rosa balancing test which afforded protection to a "quasi-suspect" class whose interests in an important (what perhaps might be termed "quasi-fundamental") right outweighed the financial and administrative burdens imposed by these rights on the state. ${ }^{73}$

right to travel of low-income persons, Cole v. Newport Housing Authority, 39 U.S.L.WW. 2320 (1st Cir. 1970), then the failure of a municipality to build public housing at all similarly restrains the right to travel. Cf. Valtierra v. Housing Authority of City of San Jose, 313 F. Supp. I (1970), prob. juris. noted, 398 U.S. 949 (1970).

71. See generally Sager, Tight Little Islands: Exclusionary Zoning, Equal Protection, and the Indigent, 21 STAN. L. REv. 767, 782-5 (1969). For cample, the Pennsyliania Supreme Court recently held that "a scheme of zoning that has an cxclusionary' purpose or result is not acceptable in Pennsylvania." Appeal of Kit-MIar Builders, Inc, 208 A.2d $765,766(\mathrm{~Pa} .1970)$.

72. See notes $56-57$ supra.

73. The balancing approach is explored in depth in Michelman, supra note 67. It merges the two traditional branches of the compelling interest standard. Its justifieation is in the political impotence of deprived minorities who cannot achicic their goals through the legislative process. See Wright, The Role of the Supreme Court in a Democtatic Society-Iudicial Activism or Restraint, 54 CORNELL L. REv. 1 (1968).

The jurisprudential difficulties with defining "fundamental interests" parallel those for defining "suspect classifications." The prototype for a "fundamental interest" is voting. But after the prototype is passed, the Court must place the label "fundamental" on interests by an ad hoc balancing test, unless it develops a full-scale ranking system. See p. 410 infra. Similarly, the prototype of a "suspeet classification" is blacks. After that prototype is passed, the courts have no clear guide for applying the "suspece" label.

The difficulties with delineating fundamental interests and suspect classifications have led at least three Supreme Court Justices to reject the two-track conceptual model of the compelling interest standard. Justice Harlan appears to have opted for a single test of rationality:

Except with respect to racial classifications, to which unique historical considerations apply, I believe the constitutional provisions assuring equal protection of the Iars impose a standard of rationality of classification, long applied in the decisions of this Court, that does not depend upon the nature of the classification or interest involved. Dandridge v. Williams, 397 U.S. 471,489 (1970) (Harlan, J. concurring) (citations omitted). On the other hand, Justice Marshall, in an opinion with which Justice Brennan concurred, appears to have taken an explicit balancing test.

The Court never undertakes to inquire for such a justifiation; rather it avoids the task by focusing upon the abstract dichotomy between two different approaches to equal protection problems which have been utilized by this Court.

In my view, equal protection analysis of this case is not appreciably advanced by the $a$ priori definition of a "right," fundamental or otherwise. Rather, concentration must be placed upon the character of the classification in question, the relative importance to individuals in the class discriminated against of the governmental benefits which they do not receive, and the asserted state interests in support of the classification.

397 U.S. at 519, 520-21 (Marshall, J. dissenting) (citations omitted). 
Yet, if courts held that SRO's were a suspect category based on such a $s u b$ rosa balancing approach, it would still not be clear how SRO's could be distinguished from numerous other sub-groups of the poor also disadvantaged by governmental action involving important rights. To adopt such a balancing approach for SRO's and other deprived minorities without explicit legislative or constitutional guidance, the courts would have to develop an elaborate ranking system for sub-groups of the poor, types of governmental processes, and interests of the state. ${ }^{74}$

\section{(3) Equal Protection: The Constitutionality of Federal Relocation Provisions}

To get away from the complicated evidentiary and jurisprudential problems in challenging treatment by the local renewal agency, SRO's could attack the constitutionality of the differential requirements for replacement housing. As a matter of law under the Weicker Amendment, ${ }^{75}$ demolished units of singles are not required to be replaced. SRO's might be able to persuade a court to invalidate this law because it violates the Equal Protection Clause by treating single men arbitrarily with regard to statutory purpose.

The Weicker Amendment provides for one-to-one replacement of all demolished low-income units for families without requiring replacement of units formerly occupied by singles. ${ }^{76}$ But the exclusion of SRO's from the Amendment is not rationally related to its legislative purpose.

One alternative, not yet accepted by any Supreme Court Justice, is a corc of citizenship rights for a subsistence standard of living or "minimum protection." The poor, like all American citizens, would have a set of rights to a subsistence standard of living which the State could not take away except for compelling reasons. Michelman, supra notc 67. Such an approach would involve the tremendous problem of setting viable minimum standards in areas without clear-cut standards like educational opportunities. Moreover, to assure minimum protection for all sub-groups of the poor, the Court would have to direct the state to expend money on specific programs.

74. The courts may be interpreted to have begun already to develop a ranking system. Developments, supra note 59, at 1120-21. On the other hand, the decision by the Court in Dandridge v. Williams, 397 U.S. 471 (1970), has been construed to mean a temporary, if not permanent, stop to the development of a ranking system. Dienes, To Fecl the Hungry: Judicial Retrenchment in Welfare Adjudication, 58 CAL. L. REv. 555 (1970).

In any case, a ranking system, within the context of limited state funds, poscs scrious jurisprudential problems since ranking in effect determines priorities for the allocation of public monies. For example, in the cases on criminal appeals, the Court said that the state had to provide funds for free counsel and free trial transcripts to indigents. Douglas v. California, 372 U.S. 353 (1963), and Rinaldi v. Yeager, 384 U.S. 305 (1966). 1f we assume that the state has a fixed amount of money to expend, the Court is implicitly reducing state expenditures on other needs of the poor, like housing or health programs. The more elaborate the judicial ranking system, the more it sets priorities for allocation of funds among types of governmental expenditures. The problem is that allocation of public funds has traditionally been considered to be a legislative rather than a judicial function.

75. 42 U.S.C.A. \$ $1455(\mathrm{~h})$.

76. Id. 
Mr. Weicker made clear on the House floor that the sole intent of his amendment was to orient renewal more toward residential than commercial or office development. ${ }^{77}$ Moreover, Mr. Weicker explicitly construed his proposal as an extension of the 1968 Proxmire Amendment, ${ }^{78}$ which provided low and moderate income housing in residential renewral projects for singles as well as for families. Thus, there was no justification for the Weicker Amendent, save accident, to exclude SRO's from its benefits.

Even if SRO's could persuade a court to invalidate Weicker, they might gain nothing for the effort and displaced families might lose all their present benefits. The courts can only invalidate the statute. For SRO's to obtain replacement housing, Congress would have to repass the law in a form which included SRO's. But the Weicker Amendment is only a recent fringe benefit for displaced families. It passed by a small margin..$^{7}$ It might very likely not be passed again.

\section{The Uniform Relocation Act}

Similarly, SRO's could have challenged the statutory basis for Additional Relocation Payments (ARP) which excluded SRO's from monetary benefits arbitrarily with regard to statutory purpose. ${ }^{\varepsilon 0}$ But Congress unexpectedly passed the Uniform Relocation Act in December, 1970,81 removing the inequities in the allocation of monetary benefits. The Uniform Relocation Act significantly increases displacement benefits and makes these benefits available to all displaced persons.

The purpose of the Uniform Relocation Act is "to establish a uniform policy for fair and equitable treatment of persons displaced . . . as a

77. Cong. REc., 90th Cong., 2d Sess., at H9972 (Oct. 23, 1969).

78. 42 U.S.C.A. $\S 1455$ (c)(2).

79. See note 77 supra.

80. 42 U.S.C.A. \& $1465(c)(1)$. The statute denied ARP to all singles who were not elderly or disabled. But ARP was explicitly designed to give a displacee monetary as. sistance in finding standard housing and paying higher rentals. HUD, Rclocation Payment Provisions Authorized by the Housing and Urban Devclopment Act of I968-Initial
Policies and Requirements, p. 4, Jan. 23, 1969 (Circular 1370.3). SRO's should not have been denied ARP because singles, like families, faced serious problems in finding ncw residences at what for them would be reasonable prices. ARP was already structured to take into consideration different types of relocatees since it was bascd on a fornula graduated according to the normal market price for each type of displacee rental. Id. at 8-9. If families in fact needed more assistance or faced higher rent increases than SRO's, the families would have been given larger amounts of money than single men.

81. The House version of the Uniform Relocation Act was passed under suspended rules of order; the bill was not put on the regular House docket becsuse it niss not expected to come out of committee this year. CoNc. REc., 9lst Cong., 2d Sess., at Hil216-25 (Dec. 7, 1970). The Uniform Relocation Act was part of the 1970 Housing and Urban Development Act, Pub. Law 91-1656, 91st Cong., 2d Sess., 1970 [hereinafter cited-as URA]. 
result of programs designed for the benefit of the public as a whole." To fulfill this purpose, Congress made clear that full relocation benefits should be given to any displaced "individual, partnership, corporation, or association."83

As a displaced individual, each SRO is eligible to receive up to $\$ 300$ for the costs of moving and for any "direct losses of tangible personal property as a result of moving." 84 Each SRO is eligible to receive a dislocation allowance of $\$ 200$, as direct compensation for having been forced to move in order that some program could be accomplished for the community as a whole. ${ }^{85}$

SRO's are also eligible for a replacement housing stipend. The purpose of the stipend is to provide a displacee with enough money to pay for a standard housing unit in an area reasonably accessible to public utilities, commercial facilities, as well as to his place of employment.80 One form of the stipend is a rent subsidy of up to $\$ 4000$ spread over a maximum of four years following displacement. ${ }^{87}$ The second form of the replacement housing stipend is a flat sum of up to $\$ 2000$ to make a down-payment for the purchase of a standard housing unit and to cover incidental expenses like recording fees and closing costs. ${ }^{88}$ Moreover, the federal government will match on a dollar for dollar basis up to another $\$ 2000$ any personal funds a displaced person applies toward a down-payment. ${ }^{89}$

With the new federal statute, displaced SRO's will be eligible for more monetary benefits than before, though two related problems still remain. First, the Uniform Relocation Act specifically states the former administrative rule that displacees cannot receive any supplementary

82. URA § 201.

83. URA § $101(5)$.

84. URA \& 202 .

85. URA $\$ 202(B)$; statutory purpose was ascertained in a telephone conversation with Richard Sullivan, Counsel for the House Committee on Public Works, which drew up the legislative basis for the Uniform Relocation Act, Dec. 24, 1970.

86. URA § 204.

87. URA § 204(1). This form of replacement housing stipend is clearly patterned after ARP, which made up the difference between the rent for a standard unit and $25 \%$ of tenant income, so the replacement housing stipend will probably be applicd according to this same administrative rule.

For a discussion of ARP, see note 80 supra. The $25 \%$ rule for the replacement housing stipend would mean that a displaced SRO who moved into public housing or began to receive rent supplements would not receive a stipend, since both programs require that he pay no more than $25 \%$ of his income for rent. 42 U.S.C.A. $\$ \S 1410(\mathrm{~g})$, 1701s. Thus, the stipend would be used only if a displaced SRO moved into housing in the private market.

88. URA § 204(a).

89. Id. This second form of the replacement housing stipend permits a displaced person to take advantage of the homeownership programs for low-income dwellings estab. lished by the federal government through interest subsidies in 1968. See pp. $421-22$ infra. 
relocation payments unless they have lived at the same address for 90 days consecutively before displacement. ${ }^{90}$ Since SRO's may not have enough money to sleep every night at their regular hotel, or may move occasionally from hotel to hotel, they may often be legally ineligible for any supplementary relocation payment. Second, the Act appears to approve by its silence the current administrative practice of giving a flat sum of $\$ 5$ for moving expenses to singles without furniture.01 TWhile many SRO's without furniture must bear the substantial costs of searching for a new residence involved with moving, the Act grants search costs only to displaced businesses and farms. ${ }^{92}$

While the Uniform Relocation Act makes significant improvements in monetary benefits for SRO's, it does not provide them with suitable replacement housing. The Act does not create new housing programs or allocate more funds to housing construction. ${ }^{33}$ The Act does not eliminate the requirement of a costly and burdensome market survey before a local agency can construct a new hotel in the renewal area. ${ }^{3 t}$ Nor does the Act include in its description of a proper replacement unit any criteria of suitability to social needs. ${ }^{95}$ Without such criteria, SRO's could easily be placed in large housing projects composed entirely of nuclear families.

Most important, the new act, like the former renewal law, requires only that a local agency give assurances that suitable relocation housing will be available. ${ }^{96}$ If, as has often happened in the past, such assurances are illusory, ${ }^{97}$ SRO's can turn only to the courts. In this forum, SRO's are no better off than before the Act's passage. The Act clearly leaves judicial review-both in terms of problems of proof and standard of review-in exactly the same state as it was before this legislation. ${ }^{\circ s}$ SRO's still face the same difficulties with making effective arguments based on violations of renewal law or on the Equal Protection Clause. ${ }^{.3}$

90. URA § 204.

91. See note 41 supra.

92. URA \& 202(a)(3).

93. The Act does, however, have a provision which allows the federal government at its discretion to allocate money out of the funds for the rencwal project to help finance the construction of housing for relocatees. URA $\S 206$.

94. See note 46 supra.

95. See notes 43-44 supra.

96. URA \& 205 (c) (3).

97. See Hearings on H.R. 14898 before the House Comm. on Public Works, 91st Cong., 2d Sess., March 5, 1970 (testimony of Edgar S. Cahn).

98. Cong. Reg., 9lst Cong., 2d Sess., at S20463 (Dec. 17, 1970).

99. In order to widen the scope of judicial review for low-income displacees like SRO's, the Senate passed its version of the Uniform Relocation Act with a provision that all displaced persons could bring actions in federal district courts under the Administrative Procedure Act (APA). 5 US.C.A. $\$ 706$. For the text of the Senate version see S.1, 
If the Uniform Relocation Act had in fact carried out its purpose of equalizing the treatment of all displaced groups, it would have extended the Weicker Amendment to cover SRO's. Not only would extension of the Weicker Amendment go a long way toward insuring the existence of adequate replacement housing, but it would also greatly reduce the proof problem in the event sufficient replacement housing was not provided. The Weicker Amendment requires that there shall be one-to-one replacement of demolished low-income family units by the construction or rehabilitation of new low-income units. ${ }^{100}$ By focusing on the provision of new units, instead of vacancies in the existing private market, the Weicker Amendment significantly changes the nature of the proof needed to show a violation of the relocation act. SRO's would have to demonstrate only that no new units had been built for them rather than that the existing housing market could not absorb displacees of their income level in a projected time period.

\section{SRO's and Federal Housing Subsidies}

The provision of monetary benefits does not create replacement housing, and the ultimate success of relocation for SRO's depends on its availability. One possible source is the private housing market. Under the Uniform Relocation Act, SRO's would be given a replacement housing stipend of up to $\$ 4000$ spread over four years to help make up the difference between $25 \%$ of their income and the rental for a private standard unit. ${ }^{101}$ But in practice, SRO's cannot find standard units on the private market. There are no new residential hotels being constructed; and existing residential hotels are usually overcrowded, substandard, or themselves slated for demolition. Most SRO's would not want to live in a private apartment house composed only of nuclear

9lst Cong., 2d Sess., $\$ 401$ (before House Amendments). On the other hand, the Housc version of the Uniform Relocation Act contained a provision that explicitly barred judicial review of all final determinations of relocation questions by the appropriate agency head. See the House version of S.1, 91st Cong., 2d Sess., § 201(a). As a compro* mise, both provisions were eliminated.

While the House provision on judicial review clearly would hurt the chances of SRO's in obtaining their rightful benefits, it is not clear whether the Senate version would have given SRO's or other displacees any more effective judicial remedies than the final compromise. The APA instructs the reviewing court to employ several criteria in. cluding both the abuse of discretion and rational purpose standards, already used in relocation cases for alleged violations of the renewal statute or the Equal Protection clause. The only new criterion which would be applicable to relocation cases is the substantial evidence rule. 5 U.S.C.A. $\S 706$. This rule has been interpreted in adminis. trative cases to mean a general test of reasonability not dissimilar to abuse of discretion or rational purpose. K. Davis, Administrative Process 915 (1951).

100. See pp. 410-11 supra.

101. See p. 412 supra. 
families; and most private landlords would be unwilling to rent to SRO's, who are seen as social deviants. Moreover, even if SRO's were allowed to rent a standard private unit, after four years many would no longer be able to meet monthly payments.

If SRO's are to be sheltered properly, they must be provided with standard housing in the public sector. The ultimate success of any relocation statute is inextricably tied to the structure of federal housing subsidies. But the existing federal programs pose nearly insurmountable barriers to their use by SRO's. While the recently passed Moorhead Bill was originally designed to remove these barriers, the bill is at best a halfway solution to SRO housing problems.

\section{A. Barriers to SRO Use of Current Federal Programs}

In the past, cities have been unable to construct new housing without federal aid. Their efforts in the area of low and moderate income housing have been therefore conditioned by the nature and quantity of available federal subsidies. While cities have always been constrained in using federal housing subsidies by red tape and inadequate funding, they have been faced with three special problems in attempting to use federal programs to serve SRO's. First, practically all federal housing programs did not allow construction of hotel-type buildings with common bathroom and dining facilities. ${ }^{102}$ Second, statutory eligibility requirements barred SRO's from many federal housing programs. If SRO's were not elderly or disabled, they were generally ineligible for existing federal shelter subsidies. Third, even if a few SRO's were eligible for certain programs under specific legal exceptions, practical difficulties often prevented even these SRO's from utilizing existing subsidies.

\section{(I) Federal Rental Programs}

Three programs have been historically aimed at supplying low and moderate income rental housing. The oldest program is public housing, ${ }^{103}$ which has been the core of the country's efforts to provide low-

102. See Miningum Property Standards for Low-Cost Housinc (HUd PG-1 Oct. 1960); Rehabilitation Guide for Residential Properties (HUD PG-50 Jan. 1968). For a discussion of the design limitations in public housing, see Ledbetter, Public Housing-A Social Experiment Seeks Acceptance, 32 LAw \& ConTEar. ProB. 490, 497-501 (1967). The only programs which are flexible enough for a hotel-type building are housing for the elderly and college housing. PROperty StANDaros fOR THE ELderly (HUD PG-16 Oct. 1966); College Housing Program (HUD PG-3 Aug. 1966).

. Since the former design limitations were clear-cut, they will not be examined in this section. For a detailed comparison between apartments and hotel-type buildings, see note 146 infra.

103. 42 U.S.C.A. $\$ \S 1401-36$. 
income units for years. A more recent program, rent supplements, ${ }^{104}$ was enacted to circumvent some of the practical barriers in the public housing program. Rent supplements are given only to tenants in Section 236 multifamily dwellings, ${ }^{105}$ which are constructed by either non-profit groups or limited dividend corporations. Except for the rent supplement tenants, 236 housing is mainly aimed at rental by moderate income residents.

Public Housing. In traditional public housing, project construction is financed through bonds issued by the local housing authority, the interest and principal of which are paid by the federal government. ${ }^{100}$ Operational and maintenance expenses remain primarily the local authority's obligation, to be met from the rents of tenants. ${ }^{107}$ Within the last few years, HUD has also developed two new types of public housing. In the leased public housing program, ${ }^{108}$ the local authority rents units from private owners which are then sublet to low-income tenants under the same conditions as units in traditional housing projects. The Turnkey series ${ }^{109}$ gives the local housing authority the flexibility of contracting out to private firms for construction or management, as well as the possibility of selling units to project tenants.

SRO's are not eligible for any of these programs unless they are elderly, disabled, or displaced by any federally sponsored program..$^{\mathbf{1 1 0}}$ Despite this legal exception in the requirements, even eligible

104. 12 U.S.C.A. § 1701s.

105. 12 U.S.C.A. \$ $1715 \mathrm{z}-1$.

106. 42 U.S.C.A. $\$ \S 1401-1436$.

107. Public Housing Administration, Low-Rfnt Manual 8217.1 (5) (1962). The Brooke Amendment in 1969 increased the federal funds provided to local authorities, but led to administrative rules reducing local revenues by limiting rents to $25 \%$ of tenant income. 42 U.S.C.A. $\$ 1410(\mathrm{~b})$ and $(\mathrm{g})$. See note 156 infra.

108. Under $\S 23$ leased housing, the local authority agrees to lease units from a private developer or owner. The lease states that at the end of a given time perlod the authority can purchase units from the private landlord for its own use or for restile to the tenants.

For a detailed discussion of this program, see EDSON, HoMEOwnERSHIP FOR LOW-INCOML Families (1969), at 19-24 (National Legal Aid and Defender Ass'n Monograph Scrics 3, 1969) [hereinafter cited as EDSON]; Burstein, New Techniques in Public Housing, 32 LAW \& ConteMP. Prob. 528, 540-55 (1967) [hereinafter cited as Burstein]; Note, Goucrn. ment Housing Assistance to Poor, 76 YALE L.J. 508 (1967) [hereinafter cited as Govern. ment Housing]; and Friedman and Krier, $A$ New Lease on Life: Section 23 Housing and the Poor, 116 U. PA. L. REv. 611 (1968) [hereinafter cited as Section 23 Housing].

109. Under the Turnkey I program, housing officials can hire a private builder to construct units for the authority. The officials choose tenants to pay the normal level of public housing rents. Then the authority begins to run the project or turns it over to a management firm under the Turnkey II program. Finally, under Turnkcy III, the authority can sell units to its tenants. When a tenant contributes a down payment of at least $\$ 350$, by self-maintenance of his unit or some other form of "sweat equity," he is given a lease-purchase contract which allows him to own his unit within twenty-five years. For a detailed discussion of the turnkey programs, see Burstein, supra notc 108, at 529-40 and EDson, supra note 108, at 7-14.

110. 42 U.S.C.A. § 1402 . 
SRO's rarely move into public housing projects.111 SRO's themselves may find traditional public housing undesirable. Accustomed to living in relatively small hotels with other singles, SRO's may not like large public housing projects composed mainly of nuclear or femaleheaded families. More importantly, public housing authorities do not want SRO's as tenants. These authorities must operate their projects on $25 \%$ of their tenants' income, and SRO's are usually in the lowest ranges of eligible incomes. Local authorities also do not want SRO's because they are often conceived to be social deviants. ${ }^{112}$ Public housing boards are composed mainly of professional men from banking, business, or real estate, who have historically sought tenants whose behavior conforms to their norms, or at least to the norms of other tenants in the projects so as to minimize social disturbances. ${ }^{113}$ To pressure SRO's into reforming or moving out, housing officials have a large range of tools, including fines for petty abuses, large repair charges tacked into rent bills, and evictions on vaguely defined grounds like "immoral or dangerous activity."114

In the new programs of leased housing and the Turnkey series, SRO's are even more at the mercy of unreceptive housing officials. No public authority is required to make use of either program; and no private landlord or developer can be forced to lease units or construct buildings.

111. For example, in Pittsburgh, of the 3,581 single persons displaced by renewal activity, only 192 were accommodated in public housing. Hearings on Housing and Urlian Development Legislation-1970 Before the Housing Subcomm. of the House Banling and Currency Comm., 9lst Cong., 2d Sess., at 318 (1970) (testimony of William Farbiss).

112. Many commentators have noted that housing officials want to inculate middleclass standards in the residents of public housing. In carrying out these patcrnalistic policies, the officials have a large range of formal and informal weapons. Sec Covernment Housing, supra note 108, at 508-15; Schoshinski, Public Landlords and Tenanls: A Survey of the Developing Law, 1969 DUKE L.J. 399.

113. Hartman and Carr, Housing Authorities Reconsidered, 33 J. AM. INST. PLASNERS 10, 12 (1969).

114. But recently the Supreme Court has made clear that public housing authorities are governmental agents who must not use their power to abridge constitutional frece doms. The Court has been ready to look behind the reasons given by housing officials to prevent retaliatory evictions for the exercise of First Amendment rights, like organizing tenants groups. Thorpe v. Housing Authority, 393 U.S. 263 (1969). A court has also invalidated illegitimacy of children as the sole criterion for rejecting applicants on both due process and equal protection grounds. Thomas v. Housing Authority, 282 F. Supp. 575 (E.D. Ark. 1967).

Moreover, in Escalera v. New York City Housing Authority, 425 F.2d 853 (2d Cir. 1970), the court has given tenants in public housing a full array of procedural protections. Before eviction, tenants must be given notice of the misconduct thought to be objectionable; access to their entire rental folders when the whole folder is being considered to determine eligibility; an opportunity to confront and cross-examine persons who sup. plied information for the tenant's folder; knowledge of the rules governing the hearing concerning termination; and a chance to present his side before an impartial official, not the project manager who instituted the eviction action.

For a discussion of landlord-tenant law in public housing projects before Escalera see Schoshinski, supra note 112; Note, Public Landlords and Private Tenants: The Eviction of "Undesirables" from Public Housing Projects, 77 Yale L.J. 988 (1968). 
When leased housing or the Turnkey series are actually implemented, SRO's will rarely be chosen as tenants. Authorities search out the most "respectable" tenants because the projects are experimental. ${ }^{115}$ In leased housing, the private landlord generally has the right to select tenants.110 In both programs, local authorities regularly screen applicants on the basis of their household habits. ${ }^{117}$

Rent Supplements. In this program, HUD pays rent supplements for low-income tenants directly to eligible private sponsors. The supplements make up the difference between the actual rent and $25 \%$ of tenant income-the same rate paid in public housing. ${ }^{118}$ Because rent supplements bypass local housing authorities, the program has been so bogged down in controversy that it has never been properly funded.11"

SRO's are eligible for rent supplements only if they are elderly, disa abled, or displaced by a federally supported renewal project. ${ }^{120}$ Again, however, practical barriers make its use by even these SRO's unlikely. It is impossible to build a residential hotel under this program alone because supplements are generally available to only $40 \%$ of the tenants in any one building. ${ }^{221}$ This legislatively contrived scarcity is aggravated by the program's gross underfunding which has led to administrative rationing among would-be participants in some regions. With so few subsidies available for any one building, there is a strong tendency for private sponsors to choose the "cream" of the poor rather than SRO's.

Section 236 Program for Multifamily Dwellings. Under the 236 program, ${ }^{122}$ the federal government provides eligible private sponsors with interest subsidies which reduce the interest rate on commercially obtained mortages to $1 \%$. The 236 program is aimed at constructing apartments, including cooperatives, at low and moderate rental levels. Eligible tenants may not earn more than $135 \%$ of the maximum income limits for local public housing.

SRO access to the 236 program is initially restricted by statutory

115. Section 23 Housing, supra note 108, at 622. Also, the leased housing program is not designed to promote the construction of whole buildings for low-income persons. One of the program's main purposes is to promote racial and economic integration. With certain exceptions, the law thus limits leased housing units to $10 \%$ of the units in any one building. 42 U.S.C.A. \& $1421 b(c)$.

116. 42 U.S.C.A. $\& 1421 \mathrm{~b}(\mathrm{~d})(1)$.

117. Section 23 Housing, supra note 108, at 622; Epson, supra note 108, at 10.11 .

118. 12 U.S.C.A. \$ 170Is (Supp. I, 1965). For a full discussion of the program, sce Government Housing, supra note 108 , at $518-35$.

119. Estimated expenditures on rent supplements were only \$23 million for 1969.70, 27 J. OF Housing 70 (1970), though the 1969 appropriations had not used up $\$ 68$ million of the original authorization. $27 \mathrm{~J}$. OF Housing 17 (1970).

120. 12 U.S.C.A. \& $1701 \mathrm{~s}(\mathrm{c})$.

121.: 12 U.S.C.A. $\$ 1701 \mathrm{~s}(\mathrm{~h})(\mathrm{l})$ (c).

122. 12 U.S.C.A. \& 1715z-1, 
eligibility requirements. Only $10 \%$ of the units in a 236 project can generally be used for singles who are not elderly or disabled. ${ }^{123}$ Further, as in the other programs, there are practical difficulties which make even the statutory $10 \%$ figure illusory. These difficulties derive from the nature of sponsors eligible for the interest subsidies. These sponsors may be of two types-non-profit groups and limited dividend corporations. ${ }^{124}$ Non-profit groups are usually churches or civic organizations which construct housing for the local community without any monetary returns. In contrast, eligible limited dividend corporations are business ventures which have agreed to earn no more than a $6 \%$ return on their investment.

Neither the non-profit nor the limited dividend sponsor have much incentive to use the 236 program to house eligible SRO's. Non-profit groups lack the resources and expertise needed to build large apartments or residential hotels. ${ }^{125}$ In their first seven years of existence, non-profit groups generated less than 75,000 housing units throughout the entire country. ${ }^{126}$ These units tend to go to the particular constituency of the church or highly publicized minority groups like blacks.

Limited dividend corporations are even less likely than non-profit groups to construct units for SRO's. With other business investments promising returns significantly higher than $6 \%$, limited dividend corporations have not been able to attract large amounts of capital. In the few projects built, SRO's are not welcome because they cannot afford the higher rents necessary to yield a $6 \%$ profit. While Congress has recently added tax incentives for limited dividend corporations that undertake housing rehabilitation, ${ }^{127}$ these incentives offer slim chances of increasing the supply of housing for SRO's. Unless HUD

123. 12 U.S.C.A. \& 1715z-1(j)(5)(c).

124. 12 U.S.C.A. \& $1715 z-1(j)(3)$.

125. P. Niebance \& J. Pope, Residential Rehabitrmation: The Pttfalis of NoN-Pfofm SPONSORSTHIP ch. 10 (1968) [hereinafter cited as NLEBANCK \& POPE].

126. The 236 program, passed in 1968, was an outgrowth of the 221(d)(3) Bclow Mar. ket Interest Rate (BMIR) program which had been started in 1961 to promote construction and rehabilitation of units. 12 U.S.C.A. $\$ 17151$. Like 22l(d)(3) BAIIR, 236 housing provides interest subsidies to non-profit sponsors. But in this program the interest rate is reduced to $1 \%$, no state or federal agency can be a sponsor, and the loan itself is taken out from a private bank rather than from the government.

From 1961 to 1964 at interest rates of up to $41 / 8 \%$, the 221 (d)(3) BMIR program financed a total of 24,297 new units and 3,093 rehabilitated ones. In 1965 the interest rate viss reduced to $3 \%$. Starts under the program in 1965.67 totaled 50,307 for all types of units. U.S. DEPARTAIENT OF Housing aNd URBAN Developarent, STATISTICAL YearLoos 90-1 (1967); and Government Housing, supra note 108, at 515-18. In 1968, Congress began the 236 program at $1 \%$ and continued the 221(d)(3) BMIIR program at $3 \%$. In fiseal 1970, construction and major rehabilitation starts were 16,500 units under 236 and 30,000 units under 221(d)(3) BMIR. 27 J. of Housing 70 (1970).

127. Section 167(K) of the Internal Revenue Code, enacted by the Tax Reform Act of 1969. Pub. L. No. 91-172, \$ 521(a), 83 Stat. 651. 
administratively limits the tax concessions to rehabilitation of low-income housing, limited dividend sponsors will naturally repair buildings for moderate-income tenants who provide higher and safer investment returns. ${ }^{128}$

\section{(2) Homeownership Programs}

There have been three major programs for the achievement of homeownership by the federal government. ${ }^{120}$ After World War II, the federal government began the home mortgage insurance program through the Federal Housing Administration (FHA), a program designed primarily for the middle class. In 1968, the federal government created the 235 program, which is oriented toward homeownership for lowincome families, and the 237 program, which is aimed at homeownership for those low-income people with poor credit histories.

FHA Guarantee of Home Mortgages. FHA provides federal insurance on home loans for eligible holders of a commercial mortgage ${ }^{130}$ But FHA guarantees are of no value to SRO's since an amendment to the statute explicitly forbids FHA to grant or insure mortgages on any hotels, ${ }^{131}$ whether they serve the wealthy or the poor. Although the purpose of the amendment was to protect luxury hotels from competitive threats financed by the federal government, ${ }^{132}$ Congress made no exception for low-income hotels that catered to SRO's.

In Federal Housing Administration v. Darlington, ${ }^{133}$ the Supreme Court had occasion to construe the statutory language forbidding FHA

128. Note, Accelerated Depreciation for Housing Rehabilitation, 79 YALE L.J. 961 (1970). An additional problem is the apparent inability to "cash out" an investment. While the shelter created by the accelerated depreciation may be attractive, the long term prospects for rehabilitated low-income housing are generally poor. Unless a method is created by which an investor may cash out of the building without all prior tax benefits being recaptured, and without having to hold the property so long as to create unrcasonable risk, the program is unlikely to attract substantial capital.

129. For a discussion of all three programs, see Sengstock \& Senstock, Homeowner* ship: A Goal for All Americans, 46 J. OF URBAN LAw 313 (1969).

130. 12 U.S.C.A. \& 1709.

131. 12 U.S.C.A. \& $1731 \mathrm{~b}$.

132. This provision in the FHA mandate was inserted by Congress in 1954 at the request of the American Hotel Association, a trade organization for owncrs of luxury hotels. The Association complained that the hotel business was in serious financinl trouble. The section was designed to ease the Association's fears of increased competition from the conversion of new federally assisted housing into hotel units. Owners of low. income hotels of course did not have the resources to lobby in Washington; and the Hotel Association did not consider the housing problems of single men. Sec, Hearings on S. 2889, S. 2938 , and S. 2949 Before the Senate Comm. on Banking and Currency, 88d Cong., 2d Sess., at 654-61 (1954). Compare the Association's suggested amendment, at 659, with the wording of 12 U.S.C.A. \$ $1731 \mathrm{~b}$.

133. 358 U.S. 84 (1958). The case involved the validity of a FHA-insured mortgage for an apartment complex which had in part been turned into a hotel. 
insurance of hotel mortgages, and exacerbated an already adverse situation for SRO's. Not satisfied to base its holdings on the limiting amendment alone, the Court declared that the amendment's statutory language only expressed the original intent of the act creating the FHA's power to finance and insure mortgages. ${ }^{134}$ In short, the federal government had never been authorized to help construct low-income hotels. The Court reasoned that the original law allowed mortgage insurance for any "dwelling" which could mean only a "permanent residence." Since the word "dwelling" appears in almost all federal housing statutes, this interpretation would prohibit federal aid to residential hotels even if all present restrictions on housing programs were abolished. Such a result would be contrary to both the usual meaning of "dwelling"135 and the Congressional goal of providing decent housing for the poor. ${ }^{130}$

Section 235 Program. The 235 program ${ }^{137}$ offers interest subsidies to those persons with incomes no higher than $135 \%$ of the maximum income for public housing in the local area. The program includes the purchase of one or two-family homes as well as the acquisition of a condominium unit. Section $\mathrm{j}$ of the 235 program $^{138}$ allows public bodies or non-profit sponsors to build units and turn them over to low and moderate income persons for purchase under the program. In either the normal 235 program or under section $\mathrm{j}$, an eligible purchaser

134. Id. at 87.

135. The dictionary defines dwelling as "a building or other shelter in which people live." Webster's Seventh NEw COLLEGIATE Dictionary 259 (1907). In other contexts, state courts have defined dwelling in a broader manner than the Darlington Courc. "Dwelling house' is a very flexible term. Its meaning depends not only on context, but on the determination of the courts not to permit public policy or justice to be defented by a word." BLACK's LAw DICTIONARY 596 (1951), citing as authority Danicls v. Commonwealth. 172 Va. 583, 1 S.E.2d 333, 335 (1939). "[Dwelling] may include an apartment building, or any structure used by human beings, partly for business and partly for residential purposes, or a building regardless of habitation." BLACk's LAw Dictionakr 590 (1951), citing as authority Gerstell v. Knight, $345 \mathrm{~Pa}$. 83, 26 A.2d 329, 330 (1912).

136. SRO's might argue that this Congressional policy, together with a later decision of a lower court, created an exception to the Darlington rule which might be cxtended to the owners of low-income hotels. In Hardy v. Savannah Apartments, Inc, 217 F. Supp. 649 (S.D. Ga. 1962), the court allowed FHA to insure the mortgage of an apartment owner in serious financial difficulties even though he converted some units to hotel rooms. The court reasoned that the owner should not lose money because he had contructed the apartments in accordance with an important public policy-the alleviation of the housing shortage after World War II. Since Congress now considers the construction of low-income units an important public policy, the courts could allow FHA to subsidize the building of low-income hotels.

There is, however, an ambivalence in the Congressional housing policy toward individuals, as opposed to families. The basic housing goal, as decermined by 42 U.S.C.A. $\S$ 1401 , is "to remedy the unsafe and unsanitary housing conditions . . for families ... that are injurious to the health, safety, and morals of the citizens of the Nation.: (Emphasis added.)

137. 12 U.S.C.A. \& $1715 z$.

138. 12 U.S.C.A. § $1715 \mathrm{z}(\mathrm{j})$. 
obtains a loan from a private bank within a given rate of interest. The federal government insures the loan and pays the bank the difference between the actual interest rate and a $1 \%$ rate.

While SRO's are legally eligible for the 235 program, in practice they are precluded from utilizing its subsidies. To participate in the $\mathbf{2 3 5}$ program, SRO's must first obtain a loan from a private bank. For most SRO's, this would be an impossible task since they have such poor credit histories or irregular sources of incomes. Even if SRO's could obtain a loan, they would not be able to afford the cost of a one or twofamily house. Although the 235 program would allow SRO's to pur* chase a condominium unit, the law requires that the unit be in a building not less than two years old, ${ }^{130}$ and most recent condominium projects are designed for moderate or high-income tenants. Besides, SRO's might not want to move into a family-oriented condominium, without other singles or communal facilities in which to congregate.

For SRO's, the 235 program's only remote possibility is section $j$. This section would permit public agencies or private sponsors to obtain financing, construct a large building, and then turn all condominium units over to SRO's only. But there is no reason to believe that housing officials and private sponsors would utilize this relatively experimental and complicated section when they have failed to provide housing for SRO's under standard, straight-forward programs.

Section 237 Program. The 237 program $^{140}$ offers all of the benefits of the 235 program to those persons with irregular credit histories or income patterns. Applicants for the 237 program are specially approved by a HUD representative who is supposed to aid the applicant in obtaining a mortgage and then offer budget, debt-management, and related counseling services. As in the 235 program, the federal government pays the difference between the actual mortgage rate and a $1 \%$ rate.

While SRO's seem exactly the type of person that the 237 program was designed to serve, 237 subsidies are by statute available only for families, particularly families living in public housing projects. ${ }^{141}$ Moreover, HUD has not received any funding for the budget, debt-management and counseling services. Even if SRO's were eligible, they would have to obtain their mortgages and handle financing on their own..$^{142}$

139. 12 U.S.C.A. \& 1715z(i).

140. 12 U.S.C.A. \$ 1715z-2.

141. Id.

142. HUD, HUD Programs, 33 (SP/MP.78 June 1969). 


\section{B. The Moorhead Bill}

The Moorhead Bill, ${ }^{143}$ as passed, was intended to eliminate the gap between the federal requirement for standard relocation units and the architectural, legal and practical obstacles to the only conceivable source of such units for SRO's-the federal housing programs. Yet, the bill provides only a partial solution to the architectural limitations on existing programs and leaves untouched almost all the legal and practical barriers.

\section{(1) Architectural Requirements}

The existing architectural regulations for federal housing programs require each unit to include bathroom and kitchen facilities within a minimum floor space of about three hundred square feet.14 Even if single men were eligible for all present housing programs, such design limitations would force both SRO's and the federal government to pay for unnecessary space. A bedroom of one hundred square feet, with the same amount per person donated to bathrooms and other forms of common space would satisfactorily meet SRO needs. ${ }^{145}$ Yet the additional one hundred feet required by legal minimums increase the cost of construction by about $\$ 2800$ for each new unit and $\$ 1600$ for each rehabilitated one. ${ }^{146}$

143. Pub. Law No. 91-1656, 91st Cong., 2d Sess. (1970) [hercinafter citcd as Moorhead Bill].

144. See note 102 supra.

145. Interview with Robert Knight, architect for the Student Community Housing Corporation's project for SRO's in New Haven, March 19, 1970.

146. Traditional construction costs run about $\$ 28$ per square foot. Prefabricated construction is, of course, less expensive, but may be unavailable because of union practices in the building trades. Rehabilitation costs run about \$16 per square foot, though demonstration projects have reduced the price to below $\$ 10$ per square foot. Estimates of construction costs are from the office of Charles Mloore, Dean of the School of Architecture at Yale University. For rehabilitation costs, sec Quirk, Wein, and Gomberg. $A$ Draft Program of Housing Reform-the Tenant Condominium, 53 CorNers. L. REv. 361 , 379-87 (1968); NifBaNcK \& POPE, supra note 125, at ch. 7.

To illustrate the cost differential between apartments and dormitory-type buildings, take a plot of land worth about $\$ 7000$, which is large enough to contain a wo-story building of $6,125 \mathrm{sq}$. ft. per story. Below is an extremely simplified sketch of two build. ings: the first along the legal minimums, the second according to actual SRO space needs. For a more sophisticated design of a SRO-type building, see Lery, supra note 4. at 576-80; Community Design Center, supra note 53 .

For new construction (at \$28 per square foot), Plan I would cost \$\$675 per person, while Plan II would cost $\$ 5000$ per person (both prices include the cost of land). If these buildings were financed at $1 \%$ over 30 jears (offered by the 235 and 236 programs), Plan I would cost about \$27.93 per person per month, while Plan II vould be \$16.10 per month. To this must be added the cost of maintenance, taxes and insurance each month, $\$ 21$ per person for Plan I and $\$ 12$ per person for Plan II (\$480 per building per year).

For rehabilitation (at $\$ 16$ per square foot with the same financing terns as the construction example), the cost of Plan $I$ is $\$ 15.78$ per person per month; the price of Plan II would be $\$ 9.02$ per person per month. Again, the monthly costs of maintenance, taxes and insurance must be added. 
At the same time, hotel-type buildings with common spaces can be much more easily adapted to SRO's needs than buildings constructed according to existing design regulations. A large common room could

The cost differential is crucial for low-income SRO's. City planners suggest that $20.25 \%$ of total income should be spent on rent. A higher percentage means cutbacks in nceded food or clothing. The average monthly income of SRO's is about $\$ 120$ per month. BoGUE, supra note 1, at 10-15. Thus, for new construction, Plan I would absorb $41 \%$ of SRO income while Plan II would take up only $23 \%$. For rehabilitation, Plan I would run about $31 \%$; Plan II would be as low as $18 \%$. (These percentages are based on total monthly costs including insurance, taxes, and maintenance.)

\section{APARTMENT DESIGN}

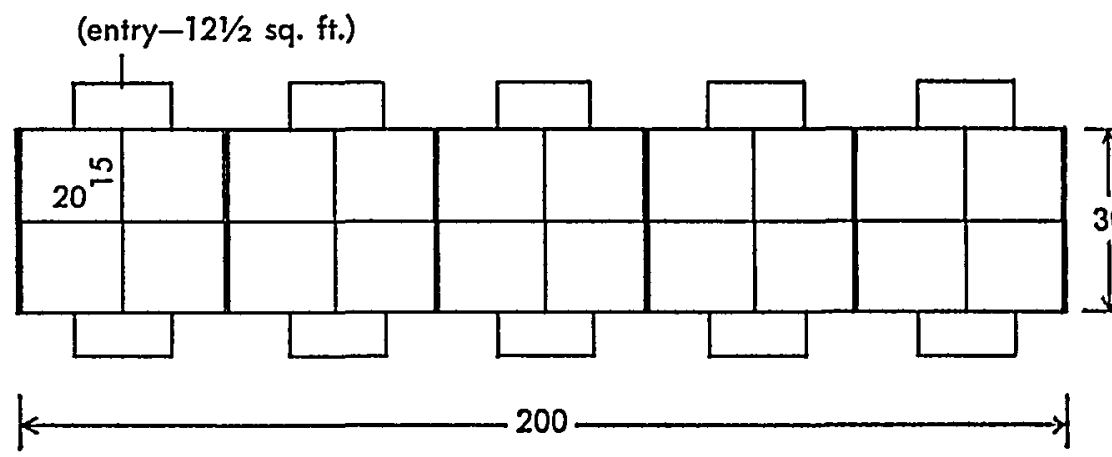

Apartments for SRO's at 300 sq. ft. legal minimum. The plan provides for 40 SRO's in a total of $12,250 \mathrm{sq}$. ft. This floor plan is for both stories. (All measurements in feet unless denoted otherwise.)

\section{HOTEL DESIGN}
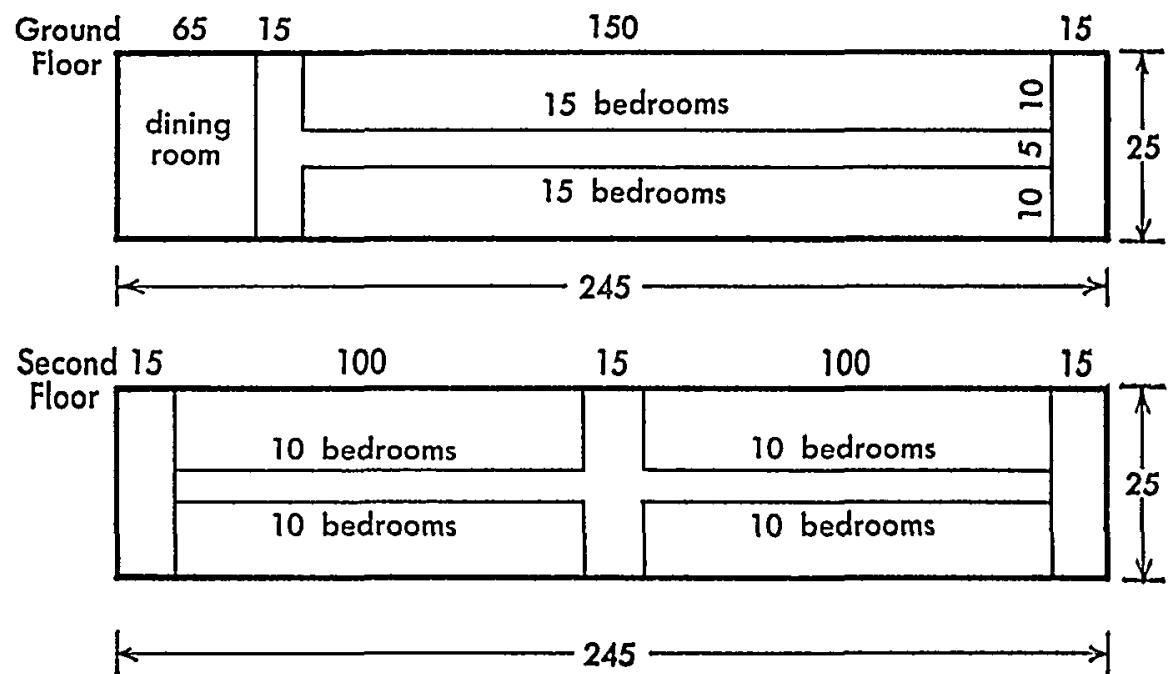

Hotel building at $100 \mathrm{sq}$. ft. per bedroom with 100 sq. ff. per person donated to common space. The plan provides for 70 SRO's in a total of 12,250 sq. ft. (All measurements in feet.) 
be used for job training during the day, a hot meal in the evening, and remedial skill courses at night. Indeed, programs which have actually been operated in a residential hotel include a living center for parolees, a halfway house for mental patients, a cooperative grocery store, as well as a physical base for different types of community organizations. ${ }^{147}$

The Moorhead Bill partially resolves the problems of existing design requirements by providing for funding of projects in which all or part of the dwelling units do not contain kitchens in both the 236 and rent supplements programs. ${ }^{148}$ As to public housing, the bill as passed provides for units without kitchens, with common dining rooms only for "elderly families."149 But the bill as passed leaves out the clause "common bathrooms and other common facilities," which was contained in the original House bill as reported out of committee.150 If residential hotels are going to be successfully constructed under these three housing programs, the buildings will need common bathrooms to keep down construction costs and large lobbies so that SRO's will have a place to congregate. By permitting units without kitchens but not allowing dining facilities for SRO's, the bill as passed fails to attack the very basic lack of decent and cheap meals for SRO's. Moreover, the bill as passed fails to encourage housing sponsors to provide space for rehabilitation programs like job training or medical facilities. ${ }^{101}$

\section{(2) Legal Eligibility}

The Moorhead Bill as passed makes SRO's who are elderly, disabled, or displaced from a federally supported project legally eligible for the public housing, rent supplements, and 236 program. ${ }^{152}$ But elderly and disabled persons were always eligible for all three programs; and displaced persons were always legally permitted to enter public housing and rent supplements projects. The only real difference is that the proportion of SRO's in 236 housing is no longer limited to $10 \%$ if there are more than that number of displaced single men who want to take advantage of the program.

In the original Moorhead Bill, public housing, rent supplements, and

147. See The Seattle Plan, supra note 8; Shapiro, supra note 4.

148. Moorhead Bill, § 114 .

149. Id., \$ 207.

150. H.R. 19436, 91st Cong., 2d Sess. (1970). For the text of the original bill, see Conc. Rec., 91st Cong., 2d Sess., H11034-5 (Dec. 2, 1970).

151. The public housing section includes some general language about the "special needs" of SRO's; but the section narrowly defines SRO housing in terms of units without kitchens.

152. Moorhead Bill, \$\$ 114 and 207. 
236 housing would have been legally available to all SRO's. ${ }^{163}$ The provisions of the original bill gave local governments an incentive to break away from the municipal policy of containment by giving city officials federal subsidies to build new housing for all SRO's. Under the bill as passed, local officials will have no incentive to reach many SRO's who are not displaced by federally subsidized projects but have been forced to live in apartments or on the streets because there were not enough residential hotels.

\section{(3) Practical Barriers}

Even for the elderly, disabled, or displaced SRO's who are eligible for residential hotels built under federal subsidies, there remain serious practical barriers.

Low-income hotels for these privileged SRO's can now be constructed under the public housing program. But the decision to take advantage of the Moorhead Bill as passed remains completely within the discretion of local housing officials. These are the same men from the same professional background who have historically viewed SRO's with distaste. ${ }^{154}$ At the same time, these officials have not been given any added economic incentives to build for SRO's. SRO's still have very low incomes and are required to pay only $25 \%$ of their income for rent. The running of a residential hotel with dining facilities will only add to the economic burden imposed by SRO's on the local housing at1thority. The Moorhead Bill as passed does provide that all extra expenses incurred in running a residential hotel can be included as operating costs. ${ }^{155}$ But housing officials must pay for the operating costs of a residential hotel, like those of all other public housing projects, mainly out of revenues. While the Housing and Urban Development Act of 1970 allows the federal government to subsidize the operating costs of local projects, the Act does not supply a large enough appropriation to make a significant impact on the structure of public housing financing. 150

The Moorhead Bill does, however, provide an alternative to the public housing program by allowing a second method of constructing residential hotels-rent supplements in 236 projects built by limited dividend or non-profit sponsors. But like the public housing approach, this method of housing SRO's is still burdened with the same practical

153. See note 150 supra.

154. See p. 417 supra.

155. Moorhead Bill, § 207.

156. Id., § 210. 
barriers that existed before. While the Moorhead Bill does make SRO's eligible for the current rent supplements program, it does not provide any new economic incentives for sponsors of 236 programs to accept SRO's. There are no additional funds allocated to the rent supplements program ear-marked for SRO's. Since the program is already oversubscribed and underfunded, ${ }^{157}$ there is no reason to believe that scarce supplements will be given in significant amounts to newcomers on the federal housing scene. More importantly, the proposed legislation does not change the requirement that no more than $40 \%$ of the tenants in any one building can receive rent supplements, ${ }^{168}$ so a residential hotel still cannot be constructed under this program alone. To finance the remaining $60 \%$ of the units, eligible SRO's will have to rely on the same incentives operative under the 236 program before the Moorhead Bill.

While the new law eases architectural limits to allow limited dividend sponsors to build residential hotels under the regular 236 program, it does not alter or remove the economic disincentives which have in the past discouraged such sponsors from housing SRO's. Limited dividend sponsors must look to rent rolls to secure the legal maximum return of $6 \%$. Without any special subsidies for very low-income tenants like SRO's, limited dividend sponsors will continue to construct apartments for moderate-income tenants in the highest eligible income category. ${ }^{120}$

The only remaining alternative for SRO's under the bill is sponsorship of 236 housing by non-profit groups. But again the proposed legislation ignores the practical barriers which have prevented non-profit groups from serving SRO's under existing programs. The bill takes no steps to build up the resources or expertise of these amateur housing sponsors. ${ }^{160}$ Since most non-profit groups are used to construct projects of about a dozen garden apartments, they cannot be expected to develop a new type of domitory design and finance the building of single projects with fifty to one hundred units. Most non-profit groups are accustomed to selling their projects or acting only as a rental collection agency. They are not equipped to deal with the complicated managerial problems involved with running low-income hotels with a central kitchen.

157. See p. 418 supra.

158. See note 121 supra.

159. See pp. 419-20 supra.

160. See p. 419 supra. 


\section{IV, Homeownership for SRO's}

Even under the Uniform Relocation Act, SRO's may not receive suitable relocation housing if they rely on the local renewal agency or on the courts to enforce their legal rights. Even with the Moorhead Bill, SRO's will probably not be housed if the decision to shelter them is left to the discretion of public housing officials, the profit motives of limited dividend corporations, or the good will of non-profit sponsors.

To assure suitable replacement housing for SRO's, Congress could shift the burden of proof to the local renewal agencies in relocation suits. To meet the shelter needs of SRO's effectively, Congress could significantly change the existing housing programs. Congress could deal with economic disincentives to housing SRO's by subsidizing a large proportion of the operating expenses for public housing, greatly increasing the appropriations for rent supplements, and making returns on residential hotel construction competitive with other business opportunities. At the same time, Congress could eliminate the organizational barriers to SRO housing by requiring public housing boards run by tenants, extending eligibility for rent supplements to all tenants in one building, and paying for full-time staff to help non-profit groups develop formidable projects like residential hotels.

But such large-scale changes seem politically infeasible in the near' future. For the time being, SRO's need a self-help approach that maximizes their own ability to enforce the legal requirement of standard replacement housing and to construct or rehabilitate their own residences. For SRO's driven to this status by economic conditions or for SRO's who like hotel-style living, such a self-help approach would be feasible. While SRO's who are very sick or very old would probably not be able to organize projects for themselves, these single men may best be helped by expanded government medical or social welfare programs.

A self-help program for SRO relocation and homeownership would follow the current government philosophy on aid to the disadvantaged. Congress has already made clear that self-help is a major goal of the anti-poverty legislation. ${ }^{101}$ The process of self-help is seen as the best way for low-income persons to gain a sense of responsibility and commitment to personal improvement. For similar reasons, Congress has emphasized homeownership for the poor. ${ }^{102}$ Homeownership is con-

161. 42 U.S.C.A. \& 2782(a)(3).

162. The main thrust of housing reform within the last few years has becn toward homeownership. To implement this goal, Congress passed the 1968 Housing and Urban Development Act which increased subsidies for the purchase of individual homes, 
sidered the most effective method to develop good housekeeping practices and a stake in the neighborhood environment.

Self-help would be especially important to SRO's. If they were organized to obtain relocation benefits, SRO's for the first time would exert influence on local policy. If SRO's built their own hotel, the building would provide younger, healthier residents with a physical base around which to organize politically. With their own property, SRO's would achieve a measure of protection against present and future circumstances. Property creates an arena of privacy within which the owner is relatively free to do as he wishes. ${ }^{163}$ Since SRO's are often seen as social deviants, property would give them a protected arena in which they could live in their own unique style. Homeownership imposes an obligation on the government to pay eminent domain costs. With their own residences, SRO's could not be removed at the discretion of public officials or private landlords.

The key to a successful self-help program is the $\$ 2000$ down-payment which the federal government gives all SRO's displaced by a renewal or rehabilitation project under the Uniform Relocation Act. ${ }^{164}$ SRO's have already been organized for various purposes by social workers, ${ }^{165}$ who are much more receptive to their needs than city officials or private landlords. With the incentive of such a large federal grant, SRO's could be organized to pressure administrative officials. Pressure from community groups has been one of the key determinants in obtaining legal benefits in the relocation process. ${ }^{166}$ If SRO's are well-organized, they

condominiums, and cooperatives. 12 U.S.C.A. \& 1715z-1. Congress even established a National Homeownership Foundation to encourage and assist in the purchasing of residences. 12 U.S.C.A. $\S 1701$. For a discussion of the political history of homeownership in recent housing legislation, see Sengstock \& Sengstock, supra note 129, at 457-83.

163. See generally Reich, The New Property, 73 Yale L.J. 733 (1964). Reich argues that one of the main functions of property:

is to draw a boundary between public and private power. Property draws a circle around the activities of each private individual or organization. Within that circle, the owner has a greater degree of freedom than without. Outside, he must justify or explain his actions, and show his authority. Within, he is master, and the state must explain and justify any interference ....

Thus property performs the function of maintaining independence, dignity and pluralism in society by creating zones within which the majority has to yield to the owner. Whim, caprice, irrationality and "anti social" activities are given the protection of the law; the owner may do what all or most of his neighbors decry. The Bill of Rights also serves this function, but while the Bill of Rights comes into play only at extraordinary moments of conflict or crisis, property affords day-to-day protection in the ordinary affairs of life.

Id. at 77I.

164. See p. 412 supra.

165. See Shapiro, supra note 4.

166. See Note, Family Relocation in Urban Renewal, 82 HARv. L. REv. 864, 897-907 (1969). 
should be able to win a commitment of the $\$ 2000$ down-payment to finance their own building. ${ }^{167}$

With working capital, a group of SRO's could achieve some form of home-ownership as a cooperative under the federal 236 program, under which low-income hotels can now be built. ${ }^{168}$ After the hotel is built, SRO's could decide whether to sell individual units to each single man as a condominium under the 235 federal program for subsidized homeownership. ${ }^{169}$ Since cooperatives and condominiums have different characteristics, the choice between forms of ownership can reflect the social structure of each SRO group. ${ }^{170}$ In a cooperative, each SRO would have stock and an equal voting right in a housing corporation which would own the building. In a condominium, each SRO would have a property right only in his room and in an undivided share of common space. If SRO's form a tightly-knit community with pooled resources, then a cooperative should be used. If SRO's live in a relatively atomized society with little financial interdependence, then a condominium would be advisable. ${ }^{171}$

167. SRO's have shown that they can run their own hotels if given the opportunity. In San Francisco, for example, the United Filipino Association has leased the International Hotel to house low-income singles and elderly persons from the Filipino community. Although the hotel operation is well-run, the owners do not want to renew the lease when it expires in about two years. See Fisher letter, note 54 supra.

168. 12 U.S.C.A. § 1715z-1(k); and The Moorhead Bill, § 114.

169. 12 U.S.C.A. \& $1715 z(\mathrm{i})$.

170. For a detailed comparison between these two forms of ownership, see Porhoryles, The FHA Condominium: $A$ Basic Comparison with the FHA Co-operative, 31 GEO. WASH. L. Rev. 1014 (1963); Miller, Cooperative Apartments: Real Estate or Securities? 45 BostoN U.L. Rev. 465 (1965); Quirk, Wein, and Gomberg, supra note 146; and Sengstock and Sengstock, supra note 129 , at $377-457$.

171. In either program, SRO's would begin by forming a housing cooperative corporation which would get a federal loan at no or low interest for preconstruction expenses like planning and obtaining financing. 12 U.S.C.A. \$1701x(b).

The corporation itself would receive federal insurance loan subsidies or outright grants to construct or rehabilitate a low-income hotel. 12 U.S.C.A. $\S 1701 x(b)$. In the 236 cooperative and 235 condominium programs, SRO's can construct or rehabilitate lowincome housing with mortgage subsidies down to a $1 \%$ interest rate. For rehabilitation only, condominiums and cooperatives are eligible for loans of up to $\$ 10,000$ per dwelling unit at zero to $3 \%$ interest. 42 U.S.C.A. \& $1452 \mathrm{~b} ; 12$ U.S.C.A. \& $1715 \mathrm{k}(\mathrm{h})(2)(\mathrm{i})$. Of these loans, up to $\$ 15,000$ per building and $\$ 2500$ per dwelling unit may be insured by the federal government. 12 U.S.C.A. \$1703(b).

Also, non-profit sponsors could rehabilitate hotels and transform them into $235 \mathrm{con}$ dominiums. But the buildings would have to be located in a "sufficiently stable" neighborhood. 12 U.S.C.A. \$ $1715 \mathrm{z}(\mathrm{j})(3)$.

For a detailed discussion of all programs in the area of condominiums and cooperatives, see Quirk \& Wein, Homeownership for the Poor: Tenants Condominiums, the Housing and Urban Development Act of 1968, and the Rockefeller Program, 54 CoRNELL L. REv. 811 (1969).

After obtaining federal financing, the corporation could remain in operation as a cooperative; or it could transfer ownership of individual units and a share of common space to each SRO, thus forming a condominium. Since the 235(i) condominium program requires existing units, SRO's would first have to form cooperatives. Then the cooperative would transfer to each SRO his own unit and a share of common space under the 235(i) 
To carry out the complicated process of hotel construction, SRO's obviously require the assistance of local lawyers. Since the federal housing regulations are so complex, lawyers will have to act as technical advisors to SRO's - describing the range of available programs, explaining different types of communal ownership, and helping fill out applications for federal grants. ${ }^{172}$ This type of technical assistance could be provided free by lawyers from OEO or neighborhood legal services. Lawyers from these organizations would be more likely to be sympathetic to the needs of SRO's than either public officials or private housing sponsors.

After low-income hotels are built, SRO's will need help in running and maintaining the buildings. ${ }^{173}$ SRO's clearly do not have any experience in managing large projects, especially ones that require central kitchens. At least for the first year of ownership, SRO's should be able to contract for management services with groups like the YMCA or university housing officers, who are familiar with the operating problems of domitory-type buildings. The cost of these services should be paid for by the federal government in addition to the annual interest subsidies.

The most serious barrier to an effective homeormership program for SRO's is HUD. The department has a wide area of discretion in granting pre-construction loans, interest subsidies, and transfers of ownership; it can promote or discourage the utilization of technical advisors by its administrative regulations and computations of "appropriate" expenses. ${ }^{174}$ Though federal officials are not generally involved with local

program, thus disbanding the cooperative. See Rental Housing for Low-Income Families, 10 HUD HANDBOOR FHA 442.1 Oct., 1968.

In a cooperative, mortgage payments would be met by monthly rentals from all co. operative members for the whole building. In a condominium, the mortgage would be paid by each SRO for his unit plus a share of common space. With heavy federal financing, the default liability would be about the same for both forms of ownership. Technically, if one member of a cooperative cannot pay, the mortgage of the whole building is defaulted. But in a heavily subsidized project, the government will not allow one person to deprive all other members of their investments. Or the residents an insure themselves by contributing to a "slush fund" which would make payments for individuals who were in financial trouble. Berger, Homeownership for Louer Income Families: The $196 \mathrm{~S}$ Housing Act's "Cruel Hoax," 2 CoNN. L. REv. 30, 35 (1969).

172. For the potential role of lawyers, see Eoson, supra note 108.

173. Letter of May 18, 1970 from Associate Director, Program Policy and Research of the National Association of Housing and Rederelopment officials to Representative rVilliam Moorhead.

174. For the preconstruction loan, HUD determines if the non-profit organization meets the requirements of "financial responsibility and stability." 12 U.S.C.A. $\$ 1701 \times(b)$ (2). The Secretary of HUD has authority to set the time period and interest rate of the loan; he can decide to cancel part or all of the loan at any time. 12 U.S.C.A. $\$ 1701 \times(b)(1)$. At its discretion, HUD may contract with public or private groups to provide information and technical assistance to sponsors of low or moderate income housing. 12 U.S.C.A. 
social prejudices or economic constraints, they have a bureaucratic tendency to pass over applications from unusual or inexperienced housing sponsors like SRO's.

To overcome possible bureaucratic barriers to a significant SRO housing program, Congress should spell out clearly its preference for some form of homeownership and the inclusion of technical advisors as an appropriate expense. Further, Congress should broaden the high-risk 237 program to include funds earmarked for low-income hotels. ${ }^{175}$ Then despite their irregular credit and employment histories, SRO's would clearly be eligible for the housing subsidies of at least one federal program.

SRO's should not be forced to await major changes in government shelter programs or in judicial housing doctrine. With appropriate technical and legal advisors, SRO's could learn to help house themselves. Under a 237 program with larger appropriations, HUD would be obligated to apply lenient guidelines in evaluating the applications of SRO's for construction or rehabilitation of their own buildings. In turn, the organizational strength derived from the formation of such housing groups would allow SRO's effectively to pressure local agencies on renewal plans and benefits.

$\S 1701 x(a)$. When a cooperative housing project is designed under the 236 program for multi-family dwellings, HUD may include such commercial and community facilltes "as deemed adequate and appropriate to serve the occupants and surrounding neighborhood, as long as the project is predominantly residential ...." Rental Housing, supra note 171, at 6 . Units built by cooperatives may be transformed into condominiums with the prlor approval of FHA. Id. at 10.

175. See p. 422 supra. 